\title{
Grain yield and associated physiological traits of rapeseed (Brassica napus L.) cultivars under different planting dates and drought stress at the flowering stage
}

\author{
Aliakbar Shafighi, ${ }^{1}$ Mohammad Reza Ardakani, ${ }^{2}$ Amir Hossein Shirani Rad, ${ }^{3}$ \\ Mojtaba Alavifazel, ${ }^{4}$ Farnaz Rafiei ${ }^{1}$
}

${ }^{1}$ Department of Agronomy, North Tehran Branch, Islamic Azad University, Tehran; ${ }^{2}$ Department of Agronomy, Karaj Branch, Islamic Azad University, Karaj; ${ }^{3}$ Seed and Plant Improvement Institute (SPII), Agricultural Research, Education and Extension Organisation (AREEO), Karaj; ${ }^{4}$ Department of Agronomy, Ahvaz Branch, Islamic Azad University, Ahvaz, Iran

\section{Highlights}

- ES Hydromel as a new hybrid cultivar under late-season drought stress conditions is proposed in cold temperate regions with arid and semi-arid climates.

- Late sowing date has extremely caused a negative effect on the winter rapeseed's physiological traits during the cold season.

- The result of cluster analysis based on grain yield loss led to the formation of two clusters, which ES Hydromel and ES Alonso with lower yield loss were grouped in the tolerant cluster.

- ES Hydromel in the late planting date and irrigation interruption conditions obtained the lowest stomatal resistance.

- ES Hydromel on regular date and normal irrigation conditions obtained the highest leaf relative water content.

\begin{abstract}
The adverse effects of abiotic stresses have always restricted oilseed crop production, particularly in arid and semi-arid regions. On the other side, global climate change has led us to adapt planting dates and select tolerant cultivars to encounter the new climatic conditions. To evaluate the effect of late-season drought stress under different planting dates on rapeseed cultivars, an experiment was conducted as a factorial split-plot based on randomised complete block design in Karaj region-Iran, during 2015-2017. Planting date and irrigation treatments were considered in the main plots as factorial and cultivars were placed in subplots. Two planting dates were regular date (October 7) (PD1) and late plant-
\end{abstract}

Correspondence: Mohammad Reza Ardakani, Department of Agronomy, Karaj Branch, Islamic Azad University, Karaj, Iran.

E-mail: mreza.ardakani@gmail.com;

mohammadreza.ardakani@kiau.ac.ir

Key words: Chlorophyll content; cluster analysis; correlation; oilseed rape; proline content.

Received for publication: 3 May 2020.

Revision received: 25 September 2020.

Accepted for publication: 6 October 2020

${ }^{\circ}$ Copyright: the Author(s), 2021

Licensee PAGEPress, Italy

Italian Journal of Agronomy 2021; 16:1648

doi:10.4081/ija.2020.1648

This article is distributed under the terms of the Creative Commons Attribution Noncommercial License (by-nc 4.0) which permits any noncommercial use, distribution, and reproduction in any medium, provided the original author(s) and source are credited. ing date (November 6). Irrigation was also carried out at two levels of normal irrigation (NI) and irrigation interruption from flowering stage onwards. Experimental cultivars included ES Hydromel, ES Alonso, ES Darko, ES Lauren, and Ahmadi. According to the results, late-season drought stress and delayed planting date reduced leaf relative water content (LRWC), total chlorophyll content, proline, and grain yield, and increased stomatal resistance (SR), canopy temperature, and leaf soluble carbohydrates (CLS) in rapeseed cultivars. The highest grain yield (4505.6 kg ha-1) was obtained in NI conditions and PD1. Significant interactions of planting date, irrigation, and cultivar on LRWC, SR, and CLS traits indicated that the ES Hydromel was the most tolerant hybrid cultivar with the highest LRWC and the lowest SR and CLS levels compared to other ones in unfavourable conditions of late-season drought stress and delayed planting. To confirm these results, cluster analysis led to the formation of two clusters, where ES Darko, Ahmadi, and ES Lauren cultivars were placed in the sensitive cluster and ES Hydromel and ES Alonso cultivars were assigned to the tolerant cluster. Therefore, ES Hydromel can be introduced as a superior cultivar to be selected as a genotype that presents acceptable resistance under drought stress and late sowing in arid and semi-arid regions.

\section{Introduction}

A large amount of edible unsaturated oils is being supplied by oil plants all over the world. The second-largest produced oilseed is rapeseed (Brassica napus L.) across the globe, the meal of which is the second source of plant protein in animal production diet, and its oil is considered as the third main vegetable oil in the world (USDA Economic Research Service, 2020). According to the latest figures from the Food and Agriculture Organisation (FAO) in 2017, the harvested area of rapeseed in the world is about 34.7 million hectares, of which ca. 13.5 million hectares 
belong to Asia (FAO, 2019). The expansion of rapeseed cultivation has always been a creative solution in order to produce some edible oil and meal in cold temperature regions beside wheat and barley cultivation. Cultivation of high yield potential and tolerant rapeseed genotypes should be considered to meet cold temperature and water deficiency during the plant growth. Therefore, discovering high yield genotypes with plausible economic implement and acceptable qualitative features in the new cultivation condition should be considered. The development of adapted rapeseed genotypes to moderate cold temperatures in the arid and semi-arid regions can be attempted effectively. The determination of the most suitable planting date can reduce the damage and negative effects of climatic factors on all vegetative and reproduction growth stages of plants. The plant growth and development phase can be affected by changing the sowing date while soil conditions in terms of water holding capacity with considering soil structure and organic matter is important for plant tolerant to drought condition (Moslemi et al., 2011). Suitable sowing date is required for establishing a seeding that has adequate growth for appropriate winter hardiness (Nazeri et al., 2018). Leaf relative water content (LRWC) is one of the factors affecting the continuation of rapeseed crop growth under water deficit stress, which decreases the reproductive stage compared to the vegetative stress. Persisting stress leads to a continuous decrease in the LRWC during the growth season (Raza et al., 2017). Neupane et al. (2019) reported that from the flowering stage onwards, cessation of irrigation led to decreased levels of LRWC in camelina cultivars, but the amount of this decrease was different for each type. In the cultivars exposed to water deficit, LRWC was lower following the cessation of irrigation from the flowering stage onwards, and this value was lower in the cultivars that were sensitive to water deficit. The reduction of LRWC under drought stress condition is the result of water deficiency in plant leaves (Shirani Rad et al., 2014b). In rapeseed crop cultivars, drought stress significantly decreased chlorophyll content compared with complete irrigation conditions (Shekari et al., 2015). Considerable loss of pigments and disorganisation of thylakoid membranes can be caused under drought stress; therefore, a decline in chlorophyll contents is predicted. (Shekari et al., 2015). Also, the losses of lipids, pigments, and chloroplast proteins caused by oxidative stress and free radicals can be the other reason for the decreased amounts of chlorophyll $a$ and $b$ under water deficit stress (Singer et al., 2016). The osmotic regulation process is fulfilled by the compounds, such as leaf proline content (LPC), leaf soluble carbohydrates (CLS), glycine betaine, and organic acids compatible with plant metabolisms (Li et al., 2014). LPC accumulates in many plants as a multifunctional amino acid in response to abiotic stress. In many crops, free LPC remarkably accumulates in response to low water potential such as drought and salinity in canola (Sabagh et al., 2019). Despite the reduction of carbon stabilisation in stressed leaves under drought stress conditions, plants accumulate large amounts of water-soluble carbohydrates such as glucose, fructose, and sucrose, the type of which varies between species (Debaeke and Aboudrare, 2004). The root is one of the organs that plant senses the drought with. While soil water potential drops more than its threshold, the driven hormonal signals from abscisic acid are transferred to the leaves and cause stomata closure to prevent water losses through transpiration. These reactions are simultaneous with the diminution of stomatal conductivity for carbon dioxide absorption and the production of carbohydrates for the maintenance of growth and development (Aiken et al., 2015; Elferjani and Soolanayakanahally, 2018). A strong negative relationship was reported between grain yield and temperature during the repro- ductive growth stage of rapeseed genotypes. Canopy temperature (CT) and stomatal resistance (SR) are suitable indicators of drought resistance (Pasban Eslam et al., 2017). Delayed sowing reduced the grain yield (GY) of rapeseed (Shirani Rad et al., 2014a). In an experiment with delayed cultivation of spring rapeseed cultivars, a decrease of $43-63 \%$ was reported in the yield (Chen et al., 2005). A classification method for rapeseed cultivars is to use cluster analysis. There are several reports on the use of cluster analysis to identify genetic similarities between rapeseed cultivars. The dendrogram structure allows further interpretation and visualisation than other examinations (Prasad et al., 2009; Raza et al., 2019). This experiment was conducted to study the biochemical parameters of the best rapeseed cultivars of Iran under different sowing dates and drought stress at the flowering stage. The main goal of this study is to select an appropriate cultivar that can simultaneously tolerate early-season delayed planting and water deficiency at the end of the growing season, with the lowest rate of yield loss. Selecting a cultivar with high stress tolerance that is suitable for relatively late to late cultivation can add up more than 60,000 ha to the area under cultivation of rapeseed in Iran. Saving water, especially in the late-season irrigation (flowering stage), which coincides with the early irrigation of spring cultivations, is significantly important, where farmers mostly do not have enough water to devote to both cultivations. Moreover, irrigation interruption in this stage causes three times less irrigation (saving $1920 \mathrm{~m}^{3} \mathrm{ha}^{-1}$ ) than the normal irrigation conditions (control). Furthermore, for the sustainable development of cultivating this product, along with increased production per surface area, it was necessary to consider the critical factor of cultivation time limitation.

\section{Materials and methods}

This experiment was conducted at Seed and Plant Improvement Research Institute of Karaj, Iran, with $35^{\circ} 59^{\prime} \mathrm{N}$, and $50^{\circ} 55^{\prime} \mathrm{E}$, and $1313 \mathrm{~m}$ above sea level and a 30-year mean rainfall of $244 \mathrm{~mm}$. Based on climatological and weather statistics, the area falls into hot and dry with semi-arid Mediterranean climate, having 150-180 days and occasionally up to 200 dry

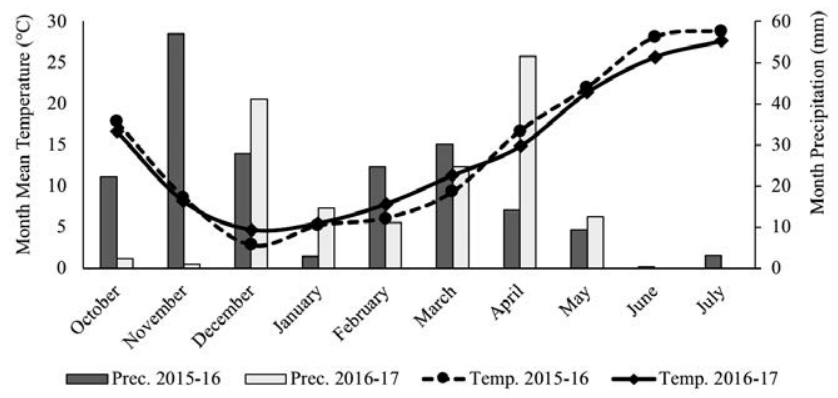

Figure 1. Meteorological information (Ambrothermic curve) of Karaj area from 2015 to 2017. 
days. Figure 1 summarises the climatological data provided by Alborz province Metrological Organisation. This research was performed as a factorial split-plot experiment in form of randomised complete block design with three replications for two years (2015-2016 and 2016-2017). Treatments were sowing date at two levels of regular planting date (October 7) (PD1) and late planting date (November 6) (PD2) and irrigation at two levels of normal irrigation (control) (NI) and irrigation interruption from flowering stage onwards (late-season drought stress) (II). Sowing date and irrigation treatments were assigned to the main plots as factorial. Five winter cultivars of rapeseed were placed in subplots, including four new rapeseed hybrid varieties of ES Hydromel, ES Alonso, ES Darko, and ES Lauren that originated in France and an open pollination cultivar, Ahmadi, with Iranian origin. The reason for selecting these cultivars was to study and compare them for cultivation in cold temperate and semi-arid areas under late cultivation and two levels of irrigation NI and II. Ten soil samples, at a depth of $0-30 \mathrm{~cm}$, were randomly collected from different parts of the field using a rotary core drill and were poured into a bag and then mixed. Then, a sample was prepared from it and transferred to the soil laboratory. Based on soil parameters (Table 1), nitrogen fertiliser (urea $150 \mathrm{~kg} \mathrm{ha}^{-1}$; one-third at sowing time, one-third at stem elongation stage and one-third at the beginning of flowering stage) and all required phosphorus (100 $\mathrm{kg} \mathrm{ha}^{-1}$ triple superphosphate at sowing time) and potassium fertilisers (50 $\mathrm{kg} \mathrm{ha}^{-1}$ potassium sulphate at sowing time) were applied in the two years. Trifluralin (Treflan EC 48\%) herbicide was used at $2.51 \mathrm{ha}^{-1}$ for the weed control before rapeseed cultivation in the plot. It was dispersed uniformly across the farm, and manure and herbicide were mixed with the soil using a light disk. Then, the weeds were controlled by manual weeding by hand following the emergence and establishment of seedlings. Oxydemeton methyl (Metasystox EC 25\%, 1.5 $\mathrm{L} \mathrm{ha}^{-1}$ ) and thiometon (Ekatin ${ }^{\circledR}$ EC $25 \%, 1 \mathrm{~L} \mathrm{ha}^{-1}$ ) insecticides were utilised in two stages, namely stemming and budding for the pest control, particularly aphids. Experimental plots were $2 \times 6 \mathrm{~m}, 30 \mathrm{~cm}$ apart between rows with plant spacing of $4 \mathrm{~cm}$ on the rows. Two lateral rows per plot were determined as marginal rows and, thus, four middle rows were utilised for measuring GY and other biochemical traits. Furrow irrigation using siphon pipes was on the basis of $80 \mathrm{~mm}$ evaporation from the surface of Class A evaporation basin (Abbasian and Shirani Rad, 2011; Safavi Fard et al., 2018). The number of irrigations in NI and II treatments was 8 and 5 times, respectively, for which 5120 and $3200 \mathrm{~m}^{3} \mathrm{ha}^{-1}$ of water were used in these treatments, respectively (accounting for rainfall during the growth period for the two years). All the physiological traits were evaluated once per growing season, through the random selection of youngest mature leaves of the third internode from top of the plant, 10 to 15 days after stress implementation, between 11:0013:00 per experimental plots in the silique formation stage. LRWC was obtained by floating the leaf (10 leaves without Petiole) on distilled water for $24 \mathrm{~h}$ at lab temperature under dim light. The turgid weight (TW) was then determined after floating, and the dry weight (DW) after the samples were dried for $24 \mathrm{~h}$ at $80^{\circ} \mathrm{C}$. Fresh weight (FW), TW and DW were used to calculate LRWC and it was estimated with Eq. 1 proposed by Ferrat and Loval (1999):

$$
\operatorname{LRWC}(\%)=\frac{(\mathrm{FW}-\mathrm{DW})}{(\mathrm{TW}-\mathrm{DW})} \times 100
$$

SR was obtained by a porometer device (Automatic Porometer AP4). To record the CT with an infrared thermometer with an emission coefficient of 0.99 , in the silique formation stage, before noon, four points were selected randomly in four directions per plot, whose average temperature was recorded as vegetation temperature. Measurements were made at a 30-degree angle to the horizon inside the canopy at the height of about 120-140 cm while marking the top of the canopy.

TCC was estimated using Eq. 2 (Arnon, 1949):

TCC: $(0.0202)(\mathrm{OD} 645)-(0.0080)(\mathrm{OD} 663) \times \mathrm{V} / \mathrm{W}$

In this equation, TCC indicates total chlorophyll content (mg $\mathrm{g}^{-1}$ of leaf fresh weight), OD denotes the absorbance of light at the equivalent wavelengths, $\mathrm{V}$ represents the volume $(\mathrm{mL})$ of acetone $80 \%$, and $\mathrm{W}$ stands for the leaf sample fresh weight.

For the measurement of LPC, 20 leaves were sampled at random from individual experimental plots and then they were relocated to the laboratory. Finally, LPC was quantified based on the procedure of Bates et al. (1973). CLS was determined through a random selection of 20 leaves from every experimental plot (Dubois et al., 1956). During physiological maturity, plants from each experimental plot (with an area of $6 \mathrm{~m}^{2}$ ) were collar-pruned and placed in two separate categories inside the experimental plot for four days in the open air to measure GY. The harvest time for PD1 was around 18 June, and the PD2 was 29 June. The plants were moved during this time to reduce moisture. Eventually, the plant moisture decreased to $12 \%$. The grains were then separated from the collar-pruned plant siliques by a small experimental combine and they were poured into a cloth bag. They were then weighed after cleaning using a precise laboratory scale. Thus, the GY of each experimental plot was calculated, and finally, the GY was determined in $\mathrm{kg} \mathrm{ha}^{-1}$. The effects of planting date, irrigation and cultivar were considered as fixed factors and statistical analysis was performed separately for the first and second year. Mean values were compared using Duncan's multiple range test at 5\% level of probability with SAS statistical software. Differences between cultivars were classified and distinguished by the cluster analysis based on all physiological traits and grain yield. The computation of Euclidean distances among group means was done with SAS software (Ver. 9) and it produced a dendrogram showing successive fusion of individuals. In the dendrogram, cultivars are presented on the vertical axis, and the horizontal axis shows the amount of Euclidean distances. Pearson's correlation coefficient

Table 1. Chemical and physical characteristics of the field soil.

\begin{tabular}{lccccccc} 
Characteristic & Soil texture & $\begin{array}{c}\text { OC } \\
(\%)\end{array}$ & pH & $\begin{array}{c}\mathrm{EC} \\
\left(\mathrm{ds} \mathrm{m} \mathrm{m}^{-1}\right)\end{array}$ & $\begin{array}{c}\mathrm{N} \\
(\%)\end{array}$ & $\begin{array}{c}\mathrm{P} \\
(\mathrm{ppm})\end{array}$ & $\begin{array}{c}\mathrm{K} \\
\left(\mathrm{mg}_{\mathrm{kg}}^{-1}\right)\end{array}$ \\
$2015-16$ & Silt loam & 0.93 & 7.8 & 1.53 & 0.07 & 13.3 & 202 \\
$2016-17$ & Silt loam & 0.95 & 7.5 & 1.41 & 0.07 & 14.5 & 194 \\
\hline
\end{tabular}

OC, organic carbon; EC, electrical conductivity; N, nitrogen; P, phosphorus; K, potassium. 
analysis and stepwise regression were performed using SAS software (Ver. 9) and SPSS (Ver. 22). Path analysis was implemented using PATH software.

\section{Results}

\section{Leaf relative water content}

The results of variance analysis of studied traits showed that the main effect of sowing date, irrigation and cultivar had a significant difference on LRWC in both studied years $(\mathrm{P}<0.01)$ (Table $2)$. The interaction effect of sowing date and irrigation as well as the interaction between planting date and cultivar in both studied years on LRWC indicated a significant difference $(\mathrm{P}<0.01)$ (Table $2)$. The interaction effect of irrigation and cultivar $(P \leq 0.05)$ and the interaction between planting date, irrigation, and cultivar $(\mathrm{P}<0.01)$ on LRWC indicated a significant difference in the first year of this research (Table 2).

LRWC decreased significantly in both years under PD2 (Table 3). Moreover, II reduced the LRWC in both years (Table 3). Among the cultivars, Ahmadi and ES Hydromel obtained the highest percentage of LRWC in the first and second year, i.e., $83.24 \%$ and $85.89 \%$, respectively (Table 3 ). A comparison of the mean interactions between the sowing date and irrigation showed that the late sowing and drought stress reduced the percentage of LRWC in both years. The highest percentage of LRWC was observed under PD1 and NI conditions, i.e., 90.15\% and 90.96\% in the first and second year, respectively (Table 4). Furthermore, the lowest percentage of LRWC was obtained under PD2 and II conditions, i.e., $75.88 \%$ and $77.65 \%$ in the first and second year, respectively (Table 4). According to the results in Table 5, late sowing date reduced the percentage of LRWC of cultivars in both years. The highest percentage of LRWC was observed in ES Hydromel cultivar (90.23\%) in the second year under PD1 conditions and Ahmadi cultivar (88.61\%) in the first year under PD2 conditions, respectively (Table 5). The interactions between sowing date, irrigation, and cultivar showed that PD2 and II reduced LRWC levels in all cultivars in the first year. The highest value of LRWC was obtained in Ahmadi with 92.10\%, under NI treatment and PD1 (Table 6). The ES Alonso and ES Darko contained the lowest LRWC level (75.31 and 75.48\% respectively) under II and PD2 treatments (Table 6). Ahmadi and ES Hydromel had the highest LRWC (76.44 and 76.25\%, respectively), in II with PD2 compared to the other cultivars (Table 6).

\section{Stomatal resistance}

The results of this study showed that the main effect of sowing date, irrigation and cultivar had a significant difference on SR in both years $(\mathrm{P}<0.01)$ (Table 2). Also, the interaction effect of sowing date and irrigation as well as sowing date and cultivar on SR were significant at $\mathrm{P}<0.01$ in both years of the experiment (Table 2 ). The interaction effect of sowing date, irrigation and cultivar showed a significant difference in the first year of the study $(\mathrm{P}<0.01)$ (Table 2). A comparison of the main effect of sowing date and irrigation indicated that the late sowing and irrigation interruption increased SR in both years (Table 3). Significant differences were observed in cultivars in terms of SR. The highest SR was obtained in ES Alonso cultivar in the first year $\left(21.28 \mathrm{~s} \mathrm{~cm}^{-1}\right)$ and ES Darko cultivar in the second year $\left(21.43 \mathrm{~s} \mathrm{~cm}^{-1}\right)$. Likewise, the lowest SR was obtained in the Ahmadi cultivar $\left(18.17 \mathrm{~s} \mathrm{~cm}^{-1}\right)$ in

Table 2. ANOVA (mean of squares) for studied traits (2015-2017).

\begin{tabular}{|c|c|c|c|c|c|c|c|c|}
\hline S.0.V. & d.f. & & & & 2015-201 & & & \\
\hline & & LRWC & SR & CT & $\mathrm{TCC}$ & LPC & CLS & GY \\
\hline 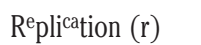 & 2 & $0.28^{\mathrm{ns}}$ & $0.50^{\mathrm{ns}}$ & $0.79^{\mathrm{ns}}$ & $0.016^{*}$ & $1.01^{\mathrm{ns}}$ & $0.10^{\mathrm{ns}}$ & $56516^{\text {ns }}$ \\
\hline Planting date (a) & 1 & $1240.97^{* *}$ & $2349.43^{* *}$ & $569.39 * *$ & $5.608^{* *}$ & $784.30^{* *}$ & $3899.72 * *$ & $38267315^{* *}$ \\
\hline Irrigation (b) & 1 & $400.57^{* *}$ & $465.43^{* *}$ & $155.18^{* *}$ & $1.132^{* *}$ & $141.09 * *$ & $644.09 * *$ & $18006186^{* *}$ \\
\hline$a \times b$ & 1 & $93.43^{* *}$ & $26.43^{* *}$ & $0.29^{\text {ns }}$ & $0.056^{*}$ & $51.48^{* *}$ & $5.16^{* *}$ & $5396^{\mathrm{ns}}$ \\
\hline Error & 6 & 0.05 & 0.26 & 0.10 & 0.008 & 0.13 & 0.21 & 61596 \\
\hline Cultivar (c) & 4 & $14.25^{* *}$ & $15.80^{* *}$ & $5.08 * *$ & $0.038 * *$ & $6.92 * *$ & $25.93^{* *}$ & $1610357^{* *}$ \\
\hline$a \times c$ & 4 & $8.96 * *$ & $6.97 * *$ & $1.64^{*}$ & $0.008^{\text {ns }}$ & $4.36^{* *}$ & $7.63^{* *}$ & $192073^{\text {ns }}$ \\
\hline $\mathrm{b} \times \mathrm{c}$ & 4 & $0.17^{*}$ & $0.35^{\mathrm{ns}}$ & $0.08^{\mathrm{ns}}$ & $0.004^{\mathrm{ns}}$ & $0.05^{\mathrm{ns}}$ & $0.56^{\mathrm{ns}}$ & $20922^{\mathrm{ns}}$ \\
\hline $\mathrm{a} \times \mathrm{b} \times \mathrm{c}$ & 4 & $0.32 * *$ & $1.27 * *$ & $0.03^{\mathrm{ns}}$ & $0.002^{\mathrm{ns}}$ & $0.02^{\mathrm{ns}}$ & $1.34^{* *}$ & $4849^{\text {ns }}$ \\
\hline Error & 32 & 0.06 & 0.20 & 0.48 & 0.005 & 0.36 & 0.25 & 283036 \\
\hline S.0.V. & d.f. & LRWC & SR & CT & $\begin{array}{c}2016-201 \\
\text { TCC }\end{array}$ & LPC & CLS & GY \\
\hline Replication (r) & 2 & $0.05^{\mathrm{ns}}$ & $1.55^{* *}$ & $0.12^{\mathrm{ns}}$ & $0.034^{* *}$ & $1.13^{*}$ & $0.003^{\text {ns }}$ & $21655^{\mathrm{ns}}$ \\
\hline Planting date (a) & 1 & $1144.50^{* *}$ & $1762.45^{* *}$ & $836.35^{* *}$ & $5.255^{* *}$ & $666.46^{* *}$ & 2742.00 ** & $42853331^{* *}$ \\
\hline Irrigation (b) & 1 & $313.14^{* *}$ & $495.64^{* *}$ & $228.11^{* *}$ & $1.315^{* *}$ & $150.85^{* *}$ & $884.10 * *$ & $14967018^{* *}$ \\
\hline$a \times b$ & 1 & $5.42 * *$ & $43.83^{* *}$ & $3.36^{*}$ & $0.015^{*}$ & $3.24 * *$ & $25.03^{* *}$ & 1112209* \\
\hline Error & 6 & 0.04 & 0.18 & 0.38 & 0.007 & 0.23 & 0.31 & 153164 \\
\hline Cultivar (c) & 4 & $9.54 * *$ & $16.36^{* *}$ & $6.12^{* *}$ & $0.034^{* *}$ & $5.60^{* *}$ & $24.89 * *$ & $1517642 *$ \\
\hline$a \times c$ & 4 & $2.77 * *$ & $5.91^{* *}$ & $1.93^{* *}$ & $0.010^{\mathrm{ns}}$ & $1.87 * *$ & $7.01^{* *}$ & $337421^{\text {ns }}$ \\
\hline$b \times c$ & 4 & $0.07^{\mathrm{ns}}$ & $0.11^{\mathrm{ns}}$ & $0.13^{\mathrm{ns}}$ & $0.002^{\mathrm{ns}}$ & $0.19^{\text {ns }}$ & $1.92 * *$ & $36291^{\text {ns }}$ \\
\hline$a \times b \times c$ & 4 & $0.06^{\mathrm{ns}}$ & $0.14^{\mathrm{ns}}$ & $0.13^{\mathrm{ns}}$ & $0.004^{\mathrm{ns}}$ & $0.08^{\mathrm{ns}}$ & $0.94^{\mathrm{ns}}$ & $14601^{\mathrm{ns}}$ \\
\hline Error & 32 & 0.17 & 0.27 & 0.36 & 0.005 & 0.30 & 0.43 & 415993 \\
\hline
\end{tabular}

S.O.V., sources of variations; d.f., degree of freedom; LRWC, leaf relative water content; SR, stomatal resistance; CT, canopy temperature; TCC, total chlorophyll content; LPC, leaf proline content; CLS, carbohydrate

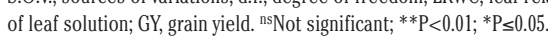


the first year and ES Hydromel cultivar $\left(19.50 \mathrm{~s} \mathrm{~cm}^{-1}\right)$ in the second year (Table 3). According to the results in Table 4, both late sowing and late-season drought stress increased SR levels in both years. The highest SR was observed in PD2 and II treatments, while SR level in the second year $\left(28.46 \mathrm{~s} \mathrm{~cm}^{-1}\right)$ was higher than the first year $\left(28.11 \mathrm{~s} \mathrm{~cm}^{-1}\right)$ (Table 4) (Figure 1). Additionally, the lowest SR was observed in both years $\left(10.02 \mathrm{~s} \mathrm{~cm}^{-1}\right.$ in the first year and $11.87 \mathrm{~s} \mathrm{~cm}^{-1}$ in the second year) under PD1 and NI conditions (Table 4). The study of interaction effect between sowing date and cultivar showed that the highest SR was obtained by ES Alonso cultivar $\left(27.15 \mathrm{~s} \mathrm{~cm}^{-1}\right)$ in the first year and Ahmadi cultivar $\left(27.60 \mathrm{~s} \mathrm{~cm}^{-1}\right)$ in the second year under PD2 condition (Table 5). Moreover, the lowest SR was observed in the Ahmadi cultivar $\left(11.45 \mathrm{~s} \mathrm{~cm}^{-1}\right)$ in the first year and ES Hydromel cultivar $(13.63 \mathrm{~s}$ $\mathrm{cm}^{-1}$ ) in the second year under PD1 condition (Table 5). SR level was uppermost in ES Alonso $\left(28.80 \mathrm{~s} \mathrm{~cm}^{-1}\right)$ in II treatment and PD2 (Table 6). The lowest SR value $\left(8.36 \mathrm{~s} \mathrm{~cm}^{-1}\right)$ was obtained in Ahmadi under the NI treatment and PD1 (Table 6). Ahmadi and ES Hydromel had a lower SR (27.46 and $\left.27.65 \mathrm{~s} \mathrm{~cm}^{-1}\right)$ than the other cultivars from II treatment under PD2 (Table 6).

\section{Canopy temperature}

The analysis of variance showed that the main effect of the sowing date, irrigation and cultivar was significant on $\mathrm{CT}$ in both years $(\mathrm{P}<0.01)$ (Table 2). Moreover, the interaction effect of sowing date and irrigation had a significant difference on $\mathrm{CT}$ in the second year of the study $(\mathrm{P} \leq 0.05)$ (Table 2$)$. The interaction effect of planting date and cultivar was significant on $\mathrm{CT}$ in the first year of the study at $\mathrm{P} \leq 0.05$ and in the second year at $\mathrm{P}<0.01$ level (Table 2). CT increased under PD2 condition in both years (Table 3 ). The treatment II significantly increased the CT in the rapeseed plant in both years (Table 3). Cultivars showed significant differences in $\mathrm{CT}$ in both years. The highest CT was obtained by the ES Alonso cultivar in the first year $\left(30.79^{\circ} \mathrm{C}\right)$ and Ahmadi cultivar in the second year $\left(31.96^{\circ} \mathrm{C}\right)$ (Table 3$)$. The lowest $\mathrm{CT}$ was observed in the Ahmadi cultivar in the first year $\left(29.03^{\circ} \mathrm{C}\right)$ and ES Hydromel cultivar in the second year $\left(30^{\circ} \mathrm{C}\right)$ (Table 3). As shown in ANOVA (Table 2), sowing date and irrigation interaction effect became significant only in the second year. Hence, the highest and lowest CT was obtained in the second year under PD2 and II at $36.38^{\circ} \mathrm{C}$ and under PD1 and NI at $25.02^{\circ} \mathrm{C}$, respectively (Table 4). Different cultivars presented different $\mathrm{CTs}$ under the influence of different sowing dates; therefore PD2 elevated CT in all cultivars (Table 5). The response of cultivars to different planting dates in both years showed different significant results. Late sowing in both years increased CT in all cultivars, which was higher in the second year of the experiment (Figure 1). In the first year of the experiment, the most highest $\left(33.72^{\circ} \mathrm{C}\right)$ and lowest $\left(25.75^{\circ} \mathrm{C}\right) \mathrm{CT}$ were obtained in ES Alonso cultivar under PD2 condition and Ahmadi cultivar under PD1 condition, respectively (Table 5). Likewise, in the second year of the experiment, the highest $\left(35.66^{\circ} \mathrm{C}\right)$ and lowest $\left(26.20^{\circ} \mathrm{C}\right) \mathrm{CT}$ were observed in the Ahmadi cultivar under PD2 condition and ES Hydromel cultivar under PD1 condition (Table 5). Among cultivars, ES Hydromel obtained the lowest CT in the second year under late sowing condition at $33.80^{\circ} \mathrm{C}$ (Table 5).

Table 3. The main effect of planting date, irrigation and cultivar on studied traits in 2015-16 and 2016-17.

\begin{tabular}{|c|c|c|c|c|c|c|c|c|}
\hline & Treatment & $\begin{array}{l}\text { LRWC } \\
(\%)\end{array}$ & $\begin{array}{c}\mathrm{SR} \\
\left(\mathrm{s} \mathrm{cm}^{-1}\right)\end{array}$ & $\begin{array}{l}\text { CT } \\
\left({ }^{\circ} \mathrm{C}\right)\end{array}$ & $\begin{array}{c}\text { TCC } \\
\text { (mg g-1 fresh } \\
\text { weight) }\end{array}$ & $\begin{array}{c}\text { LPC } \\
\text { ( }{\text { pmol } g^{-1} \text { fresh }}_{\text {weight) }}\end{array}$ & $\begin{array}{c}\text { CLS } \\
\text { ( } \mathrm{mg} \mathrm{g}^{-1} \text { fresh } \\
\text { weight) }\end{array}$ & $\begin{array}{c}\text { GY } \\
\left(\mathrm{kg} \mathrm{ha}^{-1}\right)\end{array}$ \\
\hline Year & \multicolumn{8}{|l|}{ Planting date } \\
\hline 2015-2016 & $\begin{array}{l}\text { PD1 } \\
\text { PD2 }\end{array}$ & $\begin{array}{l}86.31^{\mathrm{a}} \\
77.22^{\mathrm{b}}\end{array}$ & $\begin{array}{l}13.47^{\mathrm{b}} \\
25.98^{\mathrm{a}}\end{array}$ & $\begin{array}{l}26.85^{\mathrm{b}} \\
33.01^{\mathrm{a}}\end{array}$ & $\begin{array}{l}1.66^{\mathrm{a}} \\
1.05^{\mathrm{b}}\end{array}$ & $\begin{array}{l}18.85^{\mathrm{a}} \\
11.62^{\mathrm{b}}\end{array}$ & $\begin{array}{l}27.82^{\mathrm{b}} \\
43.94^{\mathrm{a}}\end{array}$ & $\begin{array}{l}4092^{\mathrm{a}} \\
2495^{\mathrm{b}}\end{array}$ \\
\hline 2016-2017 & $\begin{array}{l}\text { PD1 } \\
\text { PD2 }\end{array}$ & $\begin{array}{l}88.97^{a} \\
80.24^{b}\end{array}$ & $\begin{array}{l}15.60^{\mathrm{b}} \\
26.44^{\mathrm{a}}\end{array}$ & $\begin{array}{l}27.20^{\mathrm{b}} \\
34.67^{\mathrm{a}}\end{array}$ & $\begin{array}{l}1.59^{\mathrm{a}} \\
0.99^{\mathrm{b}}\end{array}$ & $\begin{array}{l}21.22^{\mathrm{a}} \\
14.56^{\mathrm{b}}\end{array}$ & $\begin{array}{l}32.61^{\mathrm{b}} \\
46.13^{\mathrm{a}}\end{array}$ & $\begin{array}{l}3727^{\mathrm{a}} \\
2036^{\mathrm{b}}\end{array}$ \\
\hline Year & \multicolumn{8}{|l|}{ Irrigation } \\
\hline 2015-2016 & $\begin{array}{l}\text { NI } \\
\text { II }\end{array}$ & $\begin{array}{l}84.35^{\mathrm{a}} \\
79.18^{\mathrm{b}}\end{array}$ & $\begin{array}{l}16.94^{\mathrm{b}} \\
22.51^{\mathrm{a}}\end{array}$ & $\begin{array}{l}28.32^{\mathrm{b}} \\
31.54^{\mathrm{a}}\end{array}$ & $\begin{array}{l}1.49^{\mathrm{a}} \\
1.22^{\mathrm{b}}\end{array}$ & $\begin{array}{l}16.77^{\mathrm{a}} \\
13.70^{\mathrm{b}}\end{array}$ & $\begin{array}{l}32.60^{\mathrm{b}} \\
39.16^{\mathrm{a}}\end{array}$ & $\begin{array}{l}3841^{\mathrm{a}} \\
2745^{\mathrm{b}}\end{array}$ \\
\hline 2016-2017 & $\begin{array}{l}\mathrm{NI} \\
\mathrm{II}\end{array}$ & $\begin{array}{l}86.89^{\mathrm{a}} \\
82.32^{\mathrm{b}}\end{array}$ & $\begin{array}{l}18.14^{\mathrm{b}} \\
23.89^{\mathrm{a}}\end{array}$ & $\begin{array}{l}28.99^{\mathrm{b}} \\
32.89^{\mathrm{a}}\end{array}$ & $\begin{array}{l}1.44^{\mathrm{a}} \\
1.14^{\mathrm{b}}\end{array}$ & $\begin{array}{l}19.47^{\mathrm{a}} \\
16.30^{\mathrm{b}}\end{array}$ & $\begin{array}{l}35.53^{\mathrm{b}} \\
43.21^{\mathrm{a}}\end{array}$ & $\begin{array}{l}3381^{\mathrm{a}} \\
2382^{\mathrm{b}}\end{array}$ \\
\hline Year & \multicolumn{8}{|l|}{ Cultivar } \\
\hline 2015-2016 & $\begin{array}{l}\text { ES Hydromel } \\
\text { ES Alonso }\end{array}$ & $\begin{array}{l}81.59^{c} \\
80.47^{\mathrm{e}}\end{array}$ & $\begin{array}{l}19.57^{\mathrm{c}} \\
21.28^{\mathrm{a}}\end{array}$ & $\begin{array}{l}29.75^{\mathrm{b}} \\
30.79^{\mathrm{a}}\end{array}$ & $\begin{array}{l}1.37^{\mathrm{b}} \\
1.28^{\mathrm{c}}\end{array}$ & $\begin{array}{l}15.18^{\mathrm{c}} \\
14.19^{\mathrm{d}}\end{array}$ & $\begin{array}{l}35.33^{\mathrm{d}} \\
37.93^{\mathrm{a}}\end{array}$ & $\begin{array}{l}3201^{\mathrm{bc}} \\
3046^{\mathrm{bc}}\end{array}$ \\
\hline & $\begin{array}{l}\text { ES Darko } \\
\text { ES Lauren }\end{array}$ & $\begin{array}{l}82.42^{\mathrm{b}} \\
81.11^{\mathrm{d}}\end{array}$ & $\begin{array}{l}19.35^{\mathrm{c}} \\
20.26^{\mathrm{b}}\end{array}$ & $\begin{array}{c}29.83^{b} \\
30.25 a^{b}\end{array}$ & $\begin{array}{l}1.36^{\mathrm{b}} \\
1.33^{\mathrm{bc}}\end{array}$ & $\begin{array}{l}15.69^{\mathrm{b}} \\
14.92^{\mathrm{c}}\end{array}$ & $\begin{array}{l}35.83^{\mathrm{c}} \\
36.39^{\mathrm{b}}\end{array}$ & $\begin{array}{l}3433^{\mathrm{ab}} \\
2931^{\mathrm{c}}\end{array}$ \\
\hline & Ahmadi & $83.24^{\mathrm{a}}$ & $18.17^{\mathrm{d}}$ & $29.03^{c}$ & $1.43^{\mathrm{a}}$ & $16.19^{a}$ & $33.91^{\mathrm{e}}$ & $3856^{\mathrm{a}}$ \\
\hline \multirow[t]{5}{*}{ 2016-2017 } & ES Hydromel & $85.89^{\mathrm{a}}$ & $19.50^{\mathrm{d}}$ & $30.00^{c}$ & $1.36^{\mathrm{a}}$ & $18.75^{\mathrm{a}}$ & $37.45^{\mathrm{d}}$ & $3383^{\mathrm{a}}$ \\
\hline & ES Alonso & $84.59^{b}$ & $20.70^{c}$ & $30.83^{b}$ & $1.29^{b}$ & $17.82^{\mathrm{bc}}$ & $39.06^{\mathrm{c}}$ & $3101^{\mathrm{ab}}$ \\
\hline & ES Darko & $84.23^{\mathrm{c}}$ & $21.43^{b}$ & $31.16^{\mathrm{b}}$ & $1.27^{\mathrm{bc}}$ & $17.75^{\mathrm{c}}$ & $39.84^{b}$ & $2545^{c}$ \\
\hline & ES Lauren & $84.86^{\mathrm{b}}$ & $20.76^{c}$ & $30.73^{b}$ & $1.31^{\mathrm{ab}}$ & $18.22^{b}$ & $39.07^{c}$ & $2785^{\mathrm{bc}}$ \\
\hline & Ahmadi & $83.45^{\mathrm{d}}$ & $22.69^{\mathrm{a}}$ & $31.96^{\mathrm{a}}$ & $1.21^{\mathrm{c}}$ & $16.89^{\mathrm{d}}$ & $41.42^{\mathrm{a}}$ & $2593^{\mathrm{bc}}$ \\
\hline
\end{tabular}

LRWC, leaf relative water content; SR, stomatal resistance; CT, canopy temperature; TCC, total chlorophyll content; LPC, leaf proline content; CLS, carbohydrate of leaf solution; GY, grain yield; PD1, regular planting

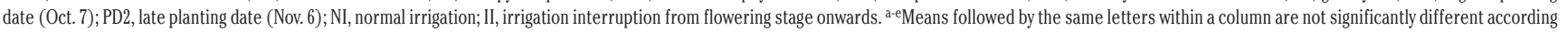
to Duncan's test $(\mathrm{P}<0.01)$. 


\section{Total chlorophyll content}

A significant difference appeared in the main effect of planting date, irrigation and cultivar on TCC in both years of the study $(\mathrm{P}<0.01)$ (Table 2). The interaction effect of planting date and irrigation showed a significant difference in both years of the study $(\mathrm{P} \leq 0.05)$ (Table 2). Late sowing date, reduced TCC in both years significantly (Table 3 ). TCC decreased in both years under the lateseason drought stress (Table 3). The highest level of TCC was observed in the Ahmadi cultivar in the first year $\left(1.43 \mathrm{mg} \mathrm{g}^{-1}\right.$ leaf fresh weight) and ES Hydromel cultivar in the second year (1.36 $\mathrm{mg} \mathrm{g}^{-1}$ leaf fresh weight). The lowest TCC was obtained by the ES Alonso cultivar in the first year $\left(1.28 \mathrm{mg} \mathrm{g}^{-1}\right.$ leaf fresh weight) and Ahmadi cultivar in the second year $\left(1.21 \mathrm{mg} \mathrm{g}^{-1}\right.$ leaf fresh weight) (Table 3). TCC showed a significant decrease under the influence of irrigation and sowing date in both years, therefore the highest $\left(1.77 \mathrm{mg} \mathrm{g}^{-1}\right.$ leaf fresh weight) and the lowest $\left(0.88 \mathrm{mg} \mathrm{g}^{-1}\right.$ leaf fresh weight) amounts of TCC were obtained in NI with PD1 and in II and PD2, respectively in the first year of the study (Table 4). Also, the uppermost (1.72 $\mathrm{mg} \mathrm{g}^{-1}$ leaf fresh weight) and the lowermost $\left(0.83 \mathrm{mg} \mathrm{g}^{-1}\right.$ leaf fresh weight) average of TCC were observed in NI with PD1 and in II and PD2, respectively in the second year of the experiment (Table 4). Thus, the amount of TCC in the first year (2015-2016) was higher than the second year (20162017) (Figure 1).

\section{Leaf proline content}

The results presented in Table 2 indicated that, the main effect of sowing date, irrigation and cultivar had significant effects on LPC at $\mathrm{P}<0.01$ level in both years of the study (Table 2). A significant difference appeared between the interaction effect of planting date and irrigation as well as planting date and cultivar on LPC at $\mathrm{P}<0.01$ level in both years (Table 2). Both late sowing and late-season drought stress reduced LPC levels in both years (Table 3). Among the cultivars, the highest LPC was obtained by the Ahmadi cultivar in the first year $\left(16.19 \mu \mathrm{m} \mathrm{g}^{-1}\right.$ leaf fresh weight $)$ and $\mathrm{ES}$

Table 4. Interaction of planting date and irrigation on studied traits in 2015-16 and 2016-17.

\begin{tabular}{|c|c|c|c|c|c|c|c|c|c|}
\hline Year & $\begin{array}{l}\text { Planting } \\
\text { date }\end{array}$ & Irrigation & $\begin{array}{c}\text { LRWC } \\
(\%)\end{array}$ & $\begin{array}{c}\mathrm{SR} \\
\left(\mathrm{s} \mathrm{cm}^{-1}\right)\end{array}$ & $\begin{array}{l}\text { CT } \\
\left({ }^{\circ} \mathrm{C}\right)\end{array}$ & $\begin{array}{c}\mathrm{TCC} \\
\text { (mg g-1 fresh } \\
\text { weight) }\end{array}$ & $\begin{array}{c}\text { LPC } \\
\text { ( } \mathrm{gmol}^{-1} \text { fresh } \\
\text { weight) }\end{array}$ & $\begin{array}{c}\text { CLS } \\
\text { (mg g } \mathrm{g}^{-1} \text { fresh } \\
\text { weight) }\end{array}$ & $\begin{array}{c}\text { GY } \\
\left(\mathrm{kg} \mathrm{ha}^{-1}\right)\end{array}$ \\
\hline \multirow[t]{3}{*}{ 2015-2016 } & PD1 & $\mathrm{NI}$ & $90.15^{\mathrm{a}}$ & $10.02^{\mathrm{d}}$ & $25.31^{\mathrm{a}}$ & $1.77^{\mathrm{a}}$ & $21.31^{\mathrm{a}}$ & $24.84^{\mathrm{d}}$ & $4649^{\mathrm{a}}$ \\
\hline & & II & $82.48^{b}$ & $16.92^{\mathrm{c}}$ & $28.39^{\mathrm{a}}$ & $1.55^{\mathrm{b}}$ & $16.39^{b}$ & $30.80^{c}$ & $3535^{\mathrm{a}}$ \\
\hline & PD2 & $\mathrm{NI}$ & $\begin{array}{l}78.55^{\mathrm{c}} \\
75 \mathrm{sed}\end{array}$ & $23.86^{\mathrm{b}}$ & $31.33^{\mathrm{a}}$ & $\begin{array}{l}1.22^{\mathrm{c}} \\
0.8 \mathrm{~d}\end{array}$ & $12.22^{\mathrm{c}}$ & $40.37^{\mathrm{b}}$ & $3033^{\mathrm{a}}$ \\
\hline \multirow{4}{*}{ 2016-2017 } & & 11 & $15.88^{\circ}$ & $28.11^{a}$ & $34.09^{a}$ & $0.88^{\circ}$ & $11.01^{4}$ & $\begin{array}{l}41.51^{4} \\
2812 \mathrm{~d}\end{array}$ & $1950^{\circ}$ \\
\hline & PDI & $\begin{array}{l}\mathrm{NI} \\
\text { II }\end{array}$ & $\begin{array}{l}90.96^{\mathrm{a}} \\
86.99^{\mathrm{b}}\end{array}$ & $\begin{array}{l}11.87^{\mathrm{a}} \\
19.32^{\mathrm{c}}\end{array}$ & $\begin{array}{l}25.02^{\mathrm{a}} \\
29.39^{\mathrm{c}}\end{array}$ & $\begin{array}{l}1.72^{\mathrm{a}} \\
1.45^{\mathrm{b}}\end{array}$ & $\begin{array}{l}22.57^{\mathrm{a}} \\
19.87^{\mathrm{b}}\end{array}$ & $\begin{array}{l}28.12^{\mathrm{d}} \\
37.09^{\mathrm{c}}\end{array}$ & $\begin{array}{l}4362^{\mathrm{a}} \\
3091^{\mathrm{b}}\end{array}$ \\
\hline & PD2 & $\mathrm{NI}$ & $82.82^{\mathrm{C}}$ & $24.42^{\mathrm{b}}$ & $32.96^{\mathrm{b}}$ & $1.16^{c}$ & $16.37^{\mathrm{c}}$ & $42.94^{b}$ & $2400^{c}$ \\
\hline & & II & $77.65^{\mathrm{d}}$ & $28.46^{\mathrm{a}}$ & $36.38^{\mathrm{a}}$ & $0.83^{\mathrm{d}}$ & $12.74^{\mathrm{d}}$ & $49.32^{\mathrm{a}}$ & $1673^{d}$ \\
\hline
\end{tabular}

LRWC, leaf relative water content; SR, stomatal resistance; CT, canopy temperature; TCC, total chlorophyll content; LPC, leaf proline content; CLS, carbohydrate of leaf solution; GY, grain yield; PD1, regular planting

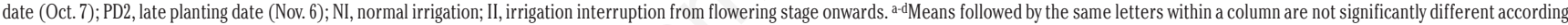
to Duncan's test $(\mathrm{P}<0.01)$.

Table 5. Interaction of planting date and cultivar on studied traits in 2015-16 and 2016-17.

\begin{tabular}{|c|c|c|c|c|c|c|c|}
\hline Year & $\begin{array}{l}\text { Planting } \\
\text { date }\end{array}$ & Cultivar & $\begin{array}{l}\text { LRWC } \\
(\%)\end{array}$ & $\begin{array}{c}\mathrm{SR} \\
\left(\mathrm{s} \mathrm{cm}^{-1}\right)\end{array}$ & $\begin{array}{l}\text { CT } \\
\left({ }^{\circ} \mathrm{C}\right)\end{array}$ & $\begin{array}{c}\text { LPC } \\
\text { ( } \mu \text { mol } g^{-1} \text { fresh } \\
\text { weight) }\end{array}$ & $\begin{array}{c}\text { CLS } \\
\text { (mg } \mathrm{g}^{-1} \text { fresh } \\
\text { weight) }\end{array}$ \\
\hline 2015-2016 & PD1 & $\begin{array}{l}\text { ES Hydromel } \\
\text { ES Alonso } \\
\text { ES Darko } \\
\text { ES Lauren } \\
\text { Ahmadi }\end{array}$ & $\begin{array}{l}85.61^{\mathrm{c}} \\
84.33^{\mathrm{e}} \\
88.03^{\mathrm{b}} \\
85.00^{\mathrm{d}} \\
88.61^{\mathrm{a}}\end{array}$ & $\begin{array}{l}13.92^{\mathrm{f}} \\
15.40^{\mathrm{d}} \\
11.98^{\mathrm{g}} \\
14.59^{\mathrm{e}} \\
11.45^{\mathrm{g}}\end{array}$ & $\begin{array}{l}27.05^{\mathrm{d}} \\
27.86^{\mathrm{d}} \\
26.21^{\mathrm{e}} \\
27.38^{\mathrm{d}} \\
25.75^{\mathrm{e}}\end{array}$ & $\begin{array}{l}18.48^{\mathrm{b}} \\
17.13^{\mathrm{c}} \\
20.04^{\mathrm{a}} \\
18.26^{\mathrm{b}} \\
20.34^{\mathrm{a}}\end{array}$ & $\begin{array}{l}27.97^{\mathrm{g}} \\
30.10^{\mathrm{e}} \\
26.42^{\mathrm{h}} \\
28.78^{\mathrm{f}} \\
25.83^{\mathrm{i}}\end{array}$ \\
\hline & PD2 & $\begin{array}{l}\text { ES Hydromel } \\
\text { ES Alonso } \\
\text { ES Darko } \\
\text { ES Lauren } \\
\text { Ahmadi }\end{array}$ & $\begin{array}{l}77.58^{\mathrm{g}} \\
76.61^{\mathrm{i}} \\
76.81^{\mathrm{i}} \\
77.22^{\mathrm{h}} \\
77.88^{\mathrm{f}}\end{array}$ & $\begin{array}{l}25.21^{\mathrm{c}} \\
27.15^{\mathrm{a}} \\
26.72^{\mathrm{a}} \\
25.94^{\mathrm{b}} \\
24.90^{\mathrm{c}}\end{array}$ & $\begin{array}{c}32.45^{\mathrm{bc}} \\
33.72^{\mathrm{a}} \\
33.46^{\mathrm{a}} \\
33.12^{\mathrm{ab}} \\
32.31^{\mathrm{c}}\end{array}$ & $\begin{array}{c}11.87^{\mathrm{de}} \\
11.26^{\mathrm{e}} \\
11.34^{\mathrm{e}} \\
11.57^{\mathrm{de}} \\
12.05^{\mathrm{d}}\end{array}$ & $\begin{array}{l}42.70^{\mathrm{c}} \\
45.76^{\mathrm{a}} \\
45.24^{\mathrm{a}} \\
44.01^{\mathrm{b}} \\
41.99^{\mathrm{d}}\end{array}$ \\
\hline 2016-2017 & PD1 & $\begin{array}{l}\text { ES Hydromel } \\
\text { ES Alonso } \\
\text { ES Darko } \\
\text { ES Lauren } \\
\text { Ahmadi }\end{array}$ & $\begin{array}{c}90.23^{\mathrm{a}} \\
89.72^{\mathrm{b}} \\
88.33^{\mathrm{cd}} \\
88.72^{\mathrm{c}} \\
87.87^{\mathrm{d}}\end{array}$ & $\begin{array}{l}13.63^{\mathrm{g}} \\
14.26^{\mathrm{f}} \\
16.42^{\mathrm{e}} \\
15.88^{\mathrm{e}} \\
17.79^{\mathrm{d}}\end{array}$ & $\begin{array}{c}26.20^{\mathrm{g}} \\
26.46^{\mathrm{g}} \\
27.67^{\mathrm{ef}} \\
27.42^{\mathrm{f}} \\
28.27^{\mathrm{e}}\end{array}$ & $\begin{array}{l}22.03^{\mathrm{a}} \\
21.80^{\mathrm{a}} \\
20.87^{\mathrm{bc}} \\
21.15^{\mathrm{b}} \\
20.26^{\mathrm{c}}\end{array}$ & $\begin{array}{l}30.53^{\mathrm{f}} \\
31.05^{\mathrm{f}} \\
33.39^{\mathrm{e}} \\
33.02^{\mathrm{e}} \\
35.06^{\mathrm{d}}\end{array}$ \\
\hline & PD2 & $\begin{array}{l}\text { ES Hydromel } \\
\text { ES Alonso } \\
\text { ES Darko } \\
\text { ES Lauren } \\
\text { Ahmadi }\end{array}$ & $\begin{array}{l}81.55^{\mathrm{e}} \\
79.46^{\mathrm{h}} \\
80.14^{\mathrm{g}} \\
81.01^{\mathrm{f}} \\
79.03^{\mathrm{h}}\end{array}$ & $\begin{array}{l}25.37^{c} \\
27.14^{a} \\
26.44^{b} \\
25.63^{c} \\
27.60^{a}\end{array}$ & $\begin{array}{c}33.80^{\mathrm{d}} \\
35.19^{\mathrm{ab}} \\
34.64^{\mathrm{bc}} \\
34.05^{\mathrm{cd}} \\
35.66^{\mathrm{a}}\end{array}$ & $\begin{array}{l}15.47^{\mathrm{d}} \\
13.85^{\mathrm{f}} \\
14.64^{\mathrm{e}} \\
15.29^{\mathrm{d}} \\
13.53^{\mathrm{f}}\end{array}$ & $\begin{array}{c}44.37^{\mathrm{c}} \\
47.07^{\mathrm{ab}} \\
46.30^{\mathrm{b}} \\
45.13^{\mathrm{c}} \\
47.77^{\mathrm{a}}\end{array}$ \\
\hline
\end{tabular}

LRWC, leaf relative water content; SR, stomatal resistance; CT, canopy temperature; LPC, leaf proline content; CLS, carbohydrate of leaf solution; PD1, regular planting date (Oct. 7); PD2, late planting date (Nov. 6). a-iMeans followed by the same letters within a column are not significantly different according to Duncan's test $(\mathrm{P}<0.01)$. 
Hydromel cultivar in the second year $\left(18.75 \mu \mathrm{m} \mathrm{g}^{-1}\right.$ leaf fresh weight). The lowest LPC was obtained by the ES Alonso cultivar in the first year $\left(14.19 \mu \mathrm{m} \mathrm{g}^{-1}\right.$ leaf fresh weight) and Ahmadi cultivar in the second year (16.89 $\mu \mathrm{m} \mathrm{g}^{-1}$ leaf fresh weight) (Table 3$)$. A comparison of the mean interactions between the sowing date and irrigation on the LPC indicated that the highest LPC was observed under PD1 and NI conditions $\left(21.31 \mu \mathrm{m} \mathrm{g}^{-1}\right.$ leaf fresh weight in the first year and $22.57 \mu \mathrm{m} \mathrm{g}^{-1}$ leaf fresh weight in the second year, respectively). The lowest LPC was observed under PD2 and II (11.01 $\mathrm{m} \mathrm{g} \mathrm{g}^{-1}$ leaf fresh weight in the first year and $12.74 \mu \mathrm{m} \mathrm{g}^{-1}$ leaf fresh weight in the second year), respectively (Table 4). LPC levels in the second year were higher than the first year under both normal and stress conditions (Figure 1). The cultivars in PD1 and PD2 had different LPC levels and PD2 reduced LPC. The highest and lowest LPCs were observed in the first year in Ahmadi cultivar under PD1 condition and ES Alonso cultivar under PD2 condition, with average of 20.34 and $11.26 \mu \mathrm{m} \mathrm{g}^{-1}$ leaf fresh weight, respectively (Table 5). Similarly, in the second year of the experiment, the highest and lowest LPCs were obtained in ES Hydromel cultivar under PD1 condition and Ahmadi cultivar under PD2 condition at 22.03 and $13.53 \mu \mathrm{m} \mathrm{g}^{-1}$ leaf fresh weight, respectively (Table 5). Moreover, ES Hydromel cultivar had higher LPC under late sowing condition in the second year $\left(15.47 \mu \mathrm{m} \mathrm{g}^{-1}\right.$ leaf fresh weight) (Table 5).

\section{Carbohydrates of leaf solution}

A significant difference appeared in the main effect of planting date, irrigation, and cultivar on CLS in both years of the study $(\mathrm{P}<0.01)$ (Table 2). The interaction effect between planting date and irrigation as well as planting date and cultivar showed a significant difference on CLS in both years $(\mathrm{P}<0.01)$ (Table 2$)$. The presented results in Table 2 showed that the interaction effect of irrigation and cultivar was significant only in the second year of the study at $\mathrm{P}<0.01$ level and the interaction effect of planting date, irrigation, and cultivar was significant only in the first year of the experiment $(\mathrm{P}<0.01)$ (Table 2$)$.

Late sowing date increased CLS in both years significantly
(Table 3). Late-season drought stress significantly increased CLS levels in both years (Table 3). Significant differences were observed in cultivars in terms of CLS. The highest and lowest CLS levels were obtained by ES Alonso cultivar (37.93 $\mathrm{mg} \mathrm{g}^{-1}$ leaf fresh weight) and Ahmadi cultivar (33.91 $\mathrm{mg} \mathrm{g}^{-1}$ leaf fresh weight) in the first year, respectively. The highest and lowest CLS levels were obtained by Ahmadi cultivar (41.42 $\mathrm{mg} \mathrm{g}^{-1}$ leaf fresh weight) and ES Hydromel cultivar (37.45 $\mathrm{mg} \mathrm{g}^{-1}$ leaf fresh weight) in the second year, respectively (Table 3 ). The study of interaction effect between sowing date and irrigation suggested that the highest CLS level was obtained under PD2 and II conditions in both years (47.51 $\mathrm{mg} \mathrm{g}^{-1}$ leaf fresh weight in the first year and $49.32 \mathrm{mg} \mathrm{g}^{-1}$ leaf fresh weight in the second year) (Table 4). The lowest CLS levels were observed under PD1 and NI conditions (24.84 $\mathrm{mg} \mathrm{g}^{-1}$ leaf fresh weight in the first year and $28.12 \mathrm{mg} \mathrm{g}^{-1}$ leaf fresh weight in the second year), respectively (Table 4). The interaction between planting date and cultivar showed that late sowing in both years significantly increased CLS in all cultivars, while this increase was higher in the second year (Figure 1). The highest and lowest CLSs were observed in the first year in ES Alonso cultivar under PD2 condition and Ahmadi cultivar under PD1 condition, with an average of 45.76 and $25.83 \mathrm{mg} \mathrm{g}^{-1}$ leaf fresh weight, respectively (Table 5). In the second year of the experiment, the highest and lowest CLSs were obtained in Ahmadi cultivar under PD2 condition and ES Hydromel cultivar under PD1 condition, with an average of 47.77 and $30.53 \mathrm{mg} \mathrm{g}^{-1}$ leaf fresh weight, respectively (Table 5). Among cultivars, the least amount of CLS (44.37 $\mathrm{mg} \mathrm{g}^{-1}$ leaf fresh weight) was found in ES Hydromel under PD2 condition and in second year of the study (Table 5). The studied cultivars responded significantly to II and PD2 in the first year of the experiment, which led to increased CLS levels. The highest CLS was observed in ES Alonso and ES Darko cultivars (48.98 and $48.67 \mathrm{mg} \mathrm{g}^{-1}$ leaf fresh weight, respectively) in II and PD2. The lowest level of CLS was recorded in the ES Darko and Ahmadi cultivars (23.96 and $23.32 \mathrm{mg} \mathrm{g}^{-1}$ leaf fresh weight, respectively) in NI treatment and PD1 (Table 6).

Table 6. Interaction of planting date, irrigation, and cultivar on studied traits in 2015-2016.

\begin{tabular}{|c|c|c|c|c|c|}
\hline Irrigation & Planting date & Cultivar & LRWC (\%) & SR $\left(\mathrm{s} \mathrm{cm}^{-1}\right)$ & CLS ( $m g \mathrm{~g}^{-1}$ fresh weight) \\
\hline $\mathrm{NI}$ & PD1 & $\begin{array}{l}\text { ES Hydromel } \\
\text { ES Alonso } \\
\text { ES Darko } \\
\text { ES Lauren } \\
\text { Ahmadi }\end{array}$ & $\begin{array}{l}89.71^{\mathrm{c}} \\
88.12^{\mathrm{e}} \\
91.67^{\mathrm{b}} \\
89.13^{\mathrm{d}} \\
92.10^{\mathrm{a}}\end{array}$ & $\begin{array}{c}10.47^{\mathrm{l}} \\
11.48^{\mathrm{k}} \\
8.85^{\mathrm{m}} \\
10.94^{\mathrm{kl}} \\
8.36^{\mathrm{m}}\end{array}$ & $\begin{array}{c}24.92^{\mathrm{l}} \\
26.42^{\mathrm{k}} \\
23.96^{\mathrm{m}} \\
25.56^{\mathrm{l}} \\
23.32^{\mathrm{m}}\end{array}$ \\
\hline & PD2 & $\begin{array}{l}\text { ES Hydromel } \\
\text { ES Alonso } \\
\text { ES Darko } \\
\text { ES Lauren } \\
\text { Ahmadi }\end{array}$ & $\begin{array}{l}81.51^{\mathrm{h}} \\
80.53^{\mathrm{i}} \\
84.38^{\mathrm{g}} \\
80.87^{\mathrm{i}} \\
85.12^{\mathrm{f}}\end{array}$ & $\begin{array}{l}17.37^{\mathrm{i}} \\
19.32^{\mathrm{g}} \\
15.11^{\mathrm{j}} \\
18.25^{\mathrm{h}} \\
14.54^{\mathrm{j}}\end{array}$ & $\begin{array}{l}31.01^{\mathrm{i}} \\
33.77^{\mathrm{g}} \\
28.89^{\mathrm{j}} \\
31.99^{\mathrm{h}} \\
28.34^{\mathrm{j}}\end{array}$ \\
\hline II & PD1 & $\begin{array}{l}\text { ES Hydromel } \\
\text { ES Alonso } \\
\text { ES Darko } \\
\text { ES Lauren } \\
\text { Ahmadi }\end{array}$ & $\begin{array}{l}78.90^{\mathrm{jk}} \\
77.91^{\mathrm{m}} \\
78.14^{\mathrm{lm}} \\
78.51^{\mathrm{lk}} \\
79.31^{\mathrm{j}}\end{array}$ & $\begin{array}{l}22.78^{\mathrm{f}} \\
25.50^{\mathrm{d}} \\
24.86^{\mathrm{d}} \\
23.85^{\mathrm{e}} \\
22.33^{\mathrm{f}}\end{array}$ & $\begin{array}{l}38.92^{\mathrm{f}} \\
42.55^{\mathrm{d}} \\
41.81^{\mathrm{d}} \\
40.40^{\mathrm{e}} \\
38.19^{\mathrm{f}}\end{array}$ \\
\hline & PD2 & $\begin{array}{l}\text { ES Hydromel } \\
\text { ES Alonso } \\
\text { ES Darko } \\
\text { ES Lauren } \\
\text { Ahmadi }\end{array}$ & $\begin{array}{l}76.25^{\mathrm{no}} \\
75.31^{\mathrm{p}} \\
75.48^{\mathrm{p}} \\
75.93^{\mathrm{o}} \\
76.44^{\mathrm{n}}\end{array}$ & $\begin{array}{c}27.65^{\mathrm{c}} \\
28.80^{\mathrm{a}} \\
28.59^{\mathrm{ab}} \\
28.02^{\mathrm{bc}} \\
27.46^{\mathrm{c}}\end{array}$ & $\begin{array}{l}46.48^{c} \\
48.98^{a} \\
48.67^{a} \\
47.63^{b} \\
45.80^{c}\end{array}$ \\
\hline
\end{tabular}

LRWC, leaf relative water content; SR, stomatal resistance; CLS, carbohydrate of leaf solution; NI, normal irrigation; II, irrigation interruption from flowering stage onwards; PD1, regular planting date (Oct. 7); PD2, late planting date (Nov. 6). a-pMeans followed by the same letters within a column are not significantly different according to Duncan's test $(\mathrm{P}<0.01)$. 


\section{Grain yield}

The results of this study showed that the main effect of sowing date, irrigation, and cultivar had a significant difference on GY in both years $(\mathrm{P} \leq 0.05$ and $\mathrm{P}<0.01)$ (Table 2$)$. Variance analysis showed that the interaction effect of planting date and irrigation was significant on GY in the second year of the study $(\mathrm{P} \leq 0.05)$ (Table 2). GY was significantly affected by the main effects of the sowing date in both years studied. Late sowing resulted in a $39 \%$ and $45.4 \%$ decrease in GY in the first and second year, respectively (Table 3). Late-season drought stress led to a $28.5 \%$ and $29.6 \%$ decrease in GY in the first and second year, respectively (Table 3). GY experienced a greater percentage decline in the second year compared to the first year (Figure 1). Among the studied cultivars, the highest and lowest GY were obtained in the first year by the Ahmadi cultivar (3856 kg ha ${ }^{-1}$ ) and ES Lauren cultivar $(2931 \mathrm{~kg}$ $\mathrm{ha}^{-1}$ ), respectively (Table 3 ). However, in the second year of the experiment the highest and lowest GY were observed in the ES Hydromel cultivar (3383 kg ha-1) and ES Darko cultivar $(2545 \mathrm{~kg}$ $\mathrm{ha}^{-1}$ ), respectively (Table 3 ). II and PD2 conditions significantly reduced GY in rapeseed cultivars in the second year of the study, with the highest (4362 $\left.\mathrm{kg} \mathrm{ha}^{-1}\right)$ and the lowest $\left(1673 \mathrm{~kg} \mathrm{ha}^{-1}\right)$ yields in NI treatment along with PD1 and in II and PD2, respectively (Table 4). The critical point in Table 4 is that the sowing date has a greater effect on rapeseed yield than irrigation (drought stress) because the GY is lower in NI with PD2 than in NI with PD1. GY experienced a greater percentage decline under PD2 and II conditions in the second year tested (approximately $61.7 \%$ ) compared to the first year (approximately 57.9\%) under similar condition (Table 4) (Figure 1).

\section{Cluster analysis}

The results of this study showed that grouping in drought stress based on GY loss led to the formation of two clusters (Figure 2). According to the study of whole groups based on the physiological traits, ES Darko, Ahmadi, and ES Lauren cultivars with higher yield losses were assigned to the sensitive cluster, and ES Hydromel and ES Alonso cultivars with lower yield loss were grouped in the tolerant cluster (Figure 2).

\section{Correlation between grain yield and physiological char- acteristics}

According to Table 7, positive significant correlations were observed between GY and such traits as TCC, LRWC, and LPC at $1 \%$ probability level. On the other hand, GY showed negative sig-

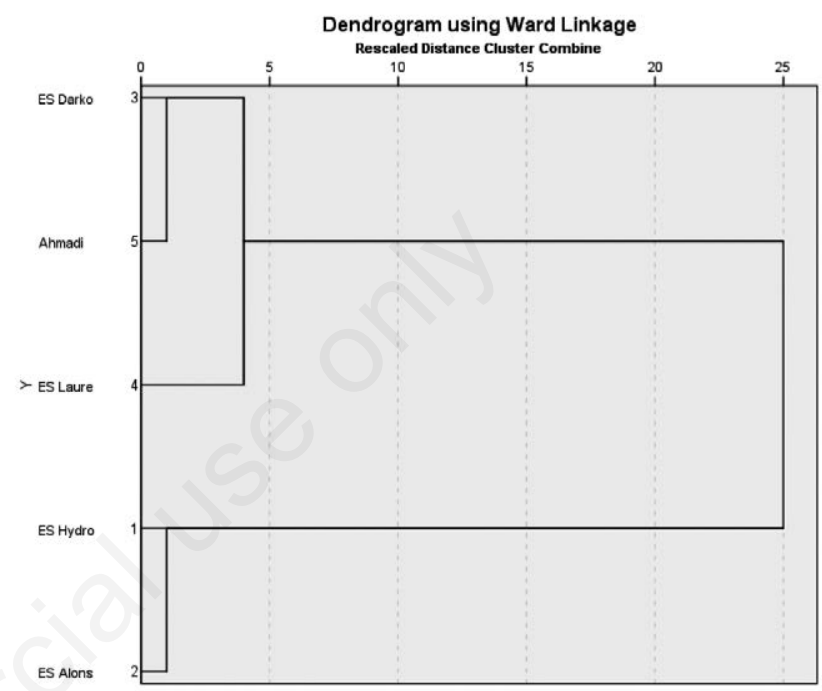

Figure 2. Representation of the dendrogram based on average correlation between the cultivars.

Table 7. Simple correlation coefficients for studied traits.

\begin{tabular}{|c|c|c|c|c|c|c|c|}
\hline & GY & LRWC & SR & CT & TCC & LPC & CLS \\
\hline GY & 1 & & & & & & \\
\hline LRWC & $0.792^{* *}$ & 1 & & & & & \\
\hline SR & $-0.887^{* *}$ & $-0.923^{* *}$ & 1 & & & & \\
\hline $\mathrm{CT}$ & $-0.873^{* *}$ & $-0.874^{* *}$ & $0.963^{* *}$ & 1 & & & \\
\hline TCC & $0.891^{* *}$ & $0.862 * *$ & $-0.941^{* *}$ & $-0.943^{* *}$ & 1 & & \\
\hline LPC & $0.767^{* *}$ & $0.976^{* *}$ & $-0.897^{* *}$ & $-0.867^{* *}$ & $0.864^{* *}$ & 1 & \\
\hline CLS & $-0.863^{* *}$ & $-0.865^{* *}$ & $0.975^{* *}$ & $0.956^{* *}$ & $-0.941^{* *}$ & $-0.834^{* *}$ & 1 \\
\hline
\end{tabular}

GY, grain yield; LRWC, leaf relative water content; SR, stomatal resistance; CT, canopy temperature; TCC, total chlorophyll content; LPC, leaf proline content; CLS, carbohydrate of leaf solution. $* * P<0.01$.

Table 8. Stepwise regression for grain yield (dependent variable) and the other traits (independent variable).

\begin{tabular}{lcccc} 
Added trait to model & 1 & 2 & 3 & \\
Intercept & -12758 & -24119 & -8611.172 & -841.137 \\
LRWC & 190.487 & 376.742 & 278.056 & 224.828 \\
\hline LPC & & -249.588 & -319.715 & -423.473 \\
CT & & & -201.655 & -176.395 \\
\hline SR & & & 0.983 & -117.459 \\
R2 & 0.971 & 0.978 & & 0.986 \\
\hline
\end{tabular}

LRWC, leaf relative water content; LPC, leaf proline content; CT, canopy temperature; SR, stomatal resistance. 
nificant correlations with SR, CT, and CLS traits at a probability level of 1\% (Table 7). Among the studied traits, TCC had a strong positive correlation (0.891) with GY (Table 7). Additionally, SR had the highest negative correlation with GY with a correlation coefficient of -0.887 (Table 7). With regard to Table 7, a significant negative correlation $(-0.923)$ between LRWC and SR appeared. Based on the correlation table (Table 7), a significant negative correlation (-0.874) was observed between LRWC and CT, as well as LRWC and CLC (-0.865). A strong positive correlation (0.963) was also appeared between SR and CT (Table 7).

\section{Stepwise regression}

Stepwise regression was used to eliminate the effects of ineffective or less effective traits and determine the most effective traits on GY in the regression model. Among the studied physiological traits, four traits were entered into the equation, namely LRWC, LPC, CT, and SR, respectively. This model had a coefficient of determination $\left(\mathrm{R}^{2}\right)$ of 0.986 ; in other words, the traits above explain more than $98 \%$ of the changes in GY. Moreover, LRWC alone accounts for $97 \%$ of the changes in GY (Table 8). It should be noted that the addition of other variables to the model did not have a significant effect on increasing $\mathrm{R}^{2}$. Figure 3 shows the regression model between GY and its most influential trait (i.e., LRWC). According to this model, for every one percent increase in LRWC (in the study area), GY increased by about $190 \mathrm{~kg} \mathrm{ha}^{-1}$.

\section{Path analysis}

Table 9 presents the path analysis of the direct and indirect effects of traits on GY. Accordingly, SR and LRWC had the highest $(-0.773)$ and lowest $(-0.013)$ direct effects on GY, respectively. According to stepwise regression, LRWC was the most influential trait in GY (Table 8). However, the results of path analysis indicated a slight direct effect of this trait on GY and a mostly indirect effect of LRWC on GY through SR (0.713), followed by CT and LPC ( 0.229 and -0.138 , respectively) (Table 9$)$. The indirect effects of CT and LPC traits on GY were also greater than their direct effects; these traits further affected GY indirectly through SR ( -0.744 and 0.692 , respectively) (Table 9).

\section{Discussion}

The results of this study are based on the decrease of LRWC under late planting date and late-season drought stress, which correspond with the results of other researchers (Zeleke et al., 2014; Shirani Rad et al., 2014b; Mamnabi et al., 2020). NI conditions probably increased the moisture in the plant roots and, eventually, the LRWC due to the high water uptake by the rapeseed plant roots. On the other hand, irrigation interruption reduced the LRWC from flowering onwards and late sowing due to its detrimental effect on LRWC-regulating metabolites (Norouzi et al., 2008; Shirani Rad et al., 2014b; Zeleke et al., 2014). Among the studied cultivars, ES Hydromel has probably been able to retain more moisture in its leaves by absorbing more water from the soil and keeping the LRWC at a higher level under II and PD2. However, LRWC can be used as a physiological trait to assess the tolerance of rapeseed genotypes to water stress since drought tolerance is genetically related to the LRWC, the total potential of leaf water, and osmotic regulation (Viger et al., 2013; Li et al., 2014; Godarzi et al., 2017; Pasban Eslam et al., 2017; Wu et al., 2018). Furthermore, despite the inappropriate distribution of rainfall in the second year of the experiment under late sowing conditions, the ES Hydromel cultivar was able to keep the LRWC at a higher level. The results regarding the late planting date and late-season drought stress showed an increased SR among the studied cultivars under the experimental condition which is in the same direction with the results of other researchers (Shirani Rad et al., 2014b; Moradi Aghdam et al., 2018; Teymoori et al., 2020). In response to drought stress, the plant may have closed the stomata as the most vital strategy to slow down perspiration and prevent the spread of water deficiency in the tissues. However, stomata closure with the cessation of photosynthesis in the early stages of dehydration will result in reduced carbon dioxide uptake and impaired growth. Under late sowing conditions, the plant may have attempted to close the stomata as a coping system to moderate the plant's short growth period and deal with the adverse environmental conditions (Elferjani and Soolanayakanahally, 2018; De Canniere et al., 2019). Among the cultivars studied, ES Hydromel probably succeeded in closing its stomata later under II conditions and PD2. Additionally, in the second year of the experiment, the plant appears to have kept its stomata closed by increasing the SR due to the poor distribution of rainfall, to deal with water deficit conditions and to maintain available water. ES Hydromel, among all, has closed its stomata later under these conditions and continues photosynthetic activity for longer due to the entry of $\mathrm{CO}_{2}$. Not only the presence of genetic differences would affect the RS of rapeseed, which would increase as the growing season approached, but also drought stress and delay in sowing resulted in increased SR. Therefore, more tolerant varieties exhibited less SR (Ghasemyan Ardestani and Shirani Rad, 2012; Safavi Fard et al., 2018).

Other researchers have also reported an increase in CT in rapeseed cultivars due to late sowing (Moradi Aghdam et al., 2018; Beheshti Monfared et al., 2020). Due to late planting as a result of the shortened growth period, the sensitive growth stages of the

Table 9. Path analysis showing direct and indirect effects on the grain yield in rapeseed cultivars.

\begin{tabular}{lcccc} 
& LRWC & SR & CT & LPC \\
LRWC & -0.013 & 0.713 & 0.229 & -0.138 \\
SR & 0.011 & -0.773 & -0.253 & 0.126 \\
\hline CT & 0.011 & -0.744 & -0.263 & 0.122 \\
LPC & -0.013 & 0.692 & 0.227 & -0.142 \\
\hline
\end{tabular}

Residual effect $=0.451$

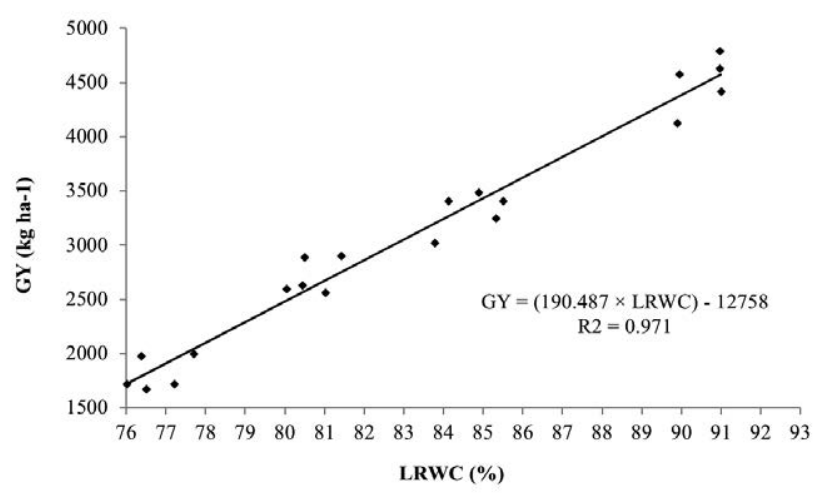

Figure 3. Representation of the regression model between leaf relative water content (LRWC) and grain yield (GY). 
plant may have encountered inappropriate environmental conditions, the stomata may have been closed, the leaf temperature may have risen, and the CT may have increased. CT is also likely to increase and decrease plant moisture due to unfavourable weather conditions and less rainfall distribution in the second year of the experiment. This increase eventually leads to closed stomata and non-transpiration of the plant, increasing leaf temperature (Araus et al., 2005). Late planting has probably led to a disrupted photosynthesis process by increasing CT, which this negative relationship has been shown in various experiments (Ergo et al., 2018). The difference between the cultivars studied in terms of CT in the planting dates tested can be attributed to genetic diversity and the interaction between genetic and environmental factors (Mason and Singh, 2014; Beheshti Monfared et al., 2020). Late sowing of ES Hydromel cultivar with a delayed stomata closure strategy compared to other cultivars seems to have lost less moisture and had a lower CT.

The results of this study are based on the decrease of TCC under late planting date and late-season drought stress, which correspond with the results of other researchers (Abu-Muriefah, 2015; Shekari et al., 2015; Mamnabi et al., 2020). Late planting and the shortened growth period seem to have caused the plant to enter the overwintering period with a weak rosette. This means that the leaves have not grown enough, the process of chloroplast formation and photosynthetic pigments has been disrupted, and TCC has been reduced. Furthermore, reduced TCC due to late planting can be attributed to degraded chloroplasts and reduced pigments when stressors significantly impact the plant (Shweta and Agrawal, 2006; Safdari Monfared et al., 2019). Unfavourable weather conditions and inappropriate rainfall distribution in the second year of the experiment could be the reason of TCC reduction. On the other hand, the reduction of photosynthesis rate during the drought stress period might result in a decline in the plant's TCC. Therefore, drought stress not only causes pigments to disappear dramatically but also prevents the formation of a thylakoid membrane. In this case, chlorophyll content is expected to decrease under drought conditions. Similarly, reduced chlorophyll content can be attributed to oxidative damage to lipids, pigments, and chloroplast proteins. Decreased TCC has been ascribed mainly to highly degraded pigments as well as dysfunctional thylakoid membranes due to drought stress (Tambussi et al., 2000; Ashraf and Harris, 2013; Ahmar et al., 2019).

The results regarding late planting on LPC showed different results in this experiment than some recorded by Safavi Fard et al. (2018), Sabagh et al. (2019) and Mamnabi et al. (2020), who reported that LPC increased in late planting and stress conditions. The results obtained in this study, which correspond with the reported data of other researchers (Gill and Tuteja, 2010; SanchezRodriguez, 2010). Various genotypes have different reactions under stress conditions, they also have different secondary metabolism mechanisms, which are high energy-consuming, and this leads to seed yield reduction. LPC accumulation is among drought stress tolerance mechanisms in plants which its production depends on genotype and stress intensity. On the other hand, stresstolerant cultivars do not always contain high LPC levels, and it was even observed that stress-sensitive cultivars showed higher LPC levels than the tolerant ones (Gill and Tuteja, 2010). Other factors might have also contributed to this change in this study. The plant might have selected less energy-intensive procedures than highenergy methods of LPC synthesis to cope with drought stress or the adverse conditions of delayed sowing. LPC appears to increase following the onset of cold as a result of late planting because elevated LPC is an essential mechanism in response to cold stress, which can play a role in repairing cellular damage (Safdari Monfared et al., 2019). The different reported LPC values can be attributed to differences in stress type, sampling steps, growth stages, genotypes, and the selection of the appropriate response by the plant in this experiment, as mentioned earlier.

With regard to the late planting date and late-season drought stress, the results showed the increase of CLS among the cultivars studied, corresponding to the reported data of rapeseed (Nazeri et al., 2018; Safdari Monfared et al., 2019). It seems that the studied genotypes have tolerated water deficiency stress through increasing the CLS content in this experiment, which is less energy-consuming for the plant than other ways such as LPC production. Osmoregulation mechanism and CLS production are different solutions against harmful conditions in plants, which decrease the amount of production and yield in plants. Therefore, a cultivar with higher energy-consumption is more sensitive to unfavourable conditions with higher yield loss. Osmoregulation is an adaptation mechanism to water stress, which can maintain related processes in low water potentials by increasing the amount of minerals in cells (Ilkaee et al., 2011; Farhoudi et al., 2015; Gogoi et al., 2017). Moieni Korbekandi et al. (2014) reported that the increased coldinduced CLS due to late planting could be explained because the increased CLS is considered as an essential mechanism in response to cold stress. The ES Hydromel cultivar had the lowest CLS and was probably less sensitive to the weather conditions of the second year and late sowing. Moreover, maybe the soluble sugars produced in this cultivar are used to produce dry matter instead of secondary metabolites to deal with the adverse environmental conditions.

With regard to the late planting and drought stress, the results showed a decrease in grain yield by $61.7 \%$ in the second year of the study. Due to inappropriate weather conditions and poor distribution of rainfall in the second year of the experiment, GY decreased more than the first year. These results are consistent with other researchers' findings that delayed sowing and drought stress decreased rapeseed production and grain yield (Faraji et al., 2008; Siadat and Hemayati, 2009; Uzun et al., 2009; Nazeri et al., 2018). Drought stress has probably reduced the number of flowers and made them wither, and as a result, fertilisation has been reduced. Rapeseed is generally susceptible to dehydration during the flowering period. It seems that drought stress prevents flowering and reduces the likelihood of silique formation, meaning that drought during flowering leads to dropped-down siliques (Shirani Rad et al., 2014a). The important point in this study is that the sowing date has a greater effect on rapeseed yield than irrigation (drought stress). Probably, delayed planting reduced the growth period, the plant did not have proper time to develop, which led to overwintering with weak rosette and finally reduced the GY of rapeseed. Decreased GY with late sowing is related to delayed flowering time, reduced flowering period, and ultimately dropped GY (Turhan et al., 2011). Planting date, quality, and quantity of the product are determined based on the effect on the length of the vegetative and reproductive growth period, striking a logical balance between these two periods. Late planting appears to have led to delayed flowering, coinciding with increased evapotranspiration time in the plant; therefore, the effect of drought stress on the plant is exacerbated (Ozer, 2003; Shirani Rad et al., 2014a). The first cluster cultivars as sensitive parents can be crossed with the second cluster cultivars as tolerant parents to provide suitable populations for drawing genetic maps and locating quantitative traits involved in drought tolerance. Therefore, according to the physiological traits evaluated in this study and the results of cluster analysis, ES Hydromel cultivar was placed in the tolerant cluster under late 
sowing and drought stress at the end of the season. The use of cluster analysis to investigate genetic diversity and clustering between rapeseed genotypes was also reported by other researchers (Choudhary and Joshi, 2001; Yousuf et al., 2011). A strong negative correlation between LRWC and SR demonstrates a close relationship among SR with LRWC and turgor pressure under II conditions. A decrease in LRWC under drought conditions leads to increased $\mathrm{SR}$, reduced $\mathrm{CO}_{2}$ emissions into the leaves, and ultimately decreased photosynthetic activity (Pasban Eslam et al., 2000b). There is also a negative correlation between LRWC and CLS that indicated LRWC reduction under II conditions or late plantinginduced cold stress, which is significantly associated with CLS accumulated as a secondary metabolite for plant osmoregulation. SR increases under II conditions; consequently, the plant closes its stomata to prevent water loss through transpiration (with a significant effect on leaf cooling). In contrast, CT as a factor to identify plant water conditions and requirements, increases under waterrestricted conditions and closed stomata followed by persistent radiation uptake (Ghasemyan Ardestani and Shirani Rad, 2012). Other researchers introduced SR, CT, and LRWC as the parameters for identifying drought-tolerant cultivars at the grain filling stage of rapeseed, with positive significant correlations between GY and drought stress at different growth stages (Arvin et al., 2010; Pasban Eslam et al., 2017). With regard to the results of stepwise regression, the most effective trait on GY was LRWC. Increased relative humidity of the leaves as the primary photosynthetic organ of the plant leads to better conditions for $\mathrm{CO}_{2}$ stabilisation. An improvement in photosynthesis rates leads to an increase in dry matter production and, eventually, GY (Pasban Eslam et al., 2000a; Fanaei et al., 2009).

The results of path analysis indicated a slight direct effect and a mostly indirect effect of LRWC on GY highly through SR, followed by CT and LPC. Under late-season drought stress and late sowing, a high SR appears to reduce $\mathrm{CO}_{2}$ input, dry matter production, and ultimately GY through the stomata closure to control water outflow from the plant. The genotype with the lowest SR has a higher GY (Liu et al., 2016). Therefore, among the studied cultivars, ES Hydromel cultivar with the lowest SR (Table 4) under PD2 and II conditions has a lower yield drop and is introduced as a suitable cultivar under test conditions. Due to the strong positive correlation (0.963) between CT and SR (Table 7), CT is likely to increase with an increase in SR and a decrease in transpiration and gas exchange. A cultivar that manages to keep CT at a lower level under PD2 and II conditions has a higher tolerability against the test condition, like ES Hydromel cultivar, which meets these conditions (Figure 2).

\section{Conclusions}

Delayed sowing and late-season drought stress are two common limiting factors in the growth and production of rapeseed in cold temperate regions with arid and semi-arid climates, such as Alborz province in Iran. Given the present water deficiency in this region, it is specifically important to select a cultivar capable of tolerating late-season drought stress and delayed sowing. ES Hydromel cultivar gained the highest average LRWC and LPC and the lowest average SR, CT, and CLS levels between the studied cultivars in the experimental conditions; it was also placed in the tolerant cultivar cluster according to the cluster analysis results. Besides, the results showed that SR had the highest degree of correlation and the most direct negative effect on GY levels and ES
Hydromel cultivar presented the lowest SR level in delayed sowing and late-season drought stress conditions among the studied traits. According to the results of this study, ES Hydromel as a new hybrid cultivar has a proper ability in coping with delayed sowing and late-season drought stress between the studied cultivars. Therefore, ES Hydromel can be introduced as a superior cultivar to be selected as a genotype that can be cultivated and present acceptable tolerance to drought stress with the lowest yield loss at the end of the growing season in cold temperate regions with arid and semi-arid climates and the cultivation of other new hybrid cultivars at different stress levels and sowing dates can be evaluated in the mentioned climate condition in the future studies.

\section{References}

Abbasian A, Shirani Rad AM, 2011. Investigation the response of rapeseed cultivars to moisture regimes in different growth stages. J. Cent. Eur. Agric. 12:353-66.

Abu-Muriefah A, 2015. Effects of paclobutrazol on growth and physiological attributes of Soybean (Glycine max L.) plants grown under water stress conditions. Int. J. Adv. Res. Biol. Sci. 2:81-93.

Ahmar S, Liaqat N, Hussain M, Salim MA, Shabbir MA, Ali MY, Noushahi HA, Bilal M, Atta B, Rizwan M, 2019. Effect of abiotic stresses on Brassica species and role of transgenic breeding for adaptation. Asian J. Res. Crop Sci. 3:1-10.

Aiken R, Baltensperger D, Krall J, Pavlista A, 2015. Planting methods affect emergence, flowering and yield of spring oilseed crops in the U.S. central High Plains. Ind. Crops Prod. 69:273-7.

Araus JL, Bort J, Steduto P, Villegas D, Royo C, 2005. Breeding cereals for Mediterranean condition: eco-physiological clues for biotechnology application. Ann. Appl. Biol. 142:129-41.

Arvin P, Azizi M, Soltani A, 2010. Comparison of yield and physiological indices of spring cultivars of oilseed rape species. Seed Plant Improv. J. 25:401-17. [In Persian].

Arnon DI, 1949. Copper enzymes in isolated chloroplasts. polyphenoloxidase in Beta vulgaris. Plant Physiol. 24:1-15.

Ashraf M, Harris PJC, 2013. Photosynthesis under stressful environments: an overview. Photosynthetica 51:163-90.

Bates LS, Waldren RD, Taere ID, 1973. Rapid determination of free proline for water stress studies. Plant Soil. 39:205-7.

Beheshti Monfared B, Noormohamadi G, Shirani Rad AH, Majidi Hervan E, 2020. Effects of sowing date and chitosan on some characters of canola (Brassica napus L.) genotypes. J. Crop Sci. Biotech. 23:65-71.

Chen C, Jackson G, Neill K, Wichman D, Johnson G, Johnson D, 2005. Determining the feasibility of early seeding canola in the Northern Great Plains. Agron. J. 97:1252-62.

Choudhary BR, Joshi P, 2001. Genetic diversity in advanced derivatives of Brassica interspecific hybrids. Euphytica. 121:1-7.

Debaeke P, Aboudrare A, 2004. Adaptation of crop management to water limited environments. Eur. J. Agron. 21:433-46.

De Canniere S, Herbst M, Rascher U, Vereecken H, Defourny P, Jonard F, 2019. Field-scale monitoring of drought stress using chlorophyll fluorescence with the coupled SCOPE-AgroC model. In: International Network on Remote Sensing of Terrestrial and Aquatic, Fluorescence, Switzerland, pp 1-15.

Dubois M, Gilles KA, Hamilton JK, Rebers PA, Smith F, 1956. Colorimetric method for determination of sugars and related substances. Anal. Chem. 28:350-6. 
Elferjani R, Soolanayakanahally R, 2018. Canola responses to drought, heat, and combined stress: shared and specific effects on carbon assimilation, seed yield, and oil composition. Front. Plant Sci. 9:1-17.

Ergo VV, Lascano R, Vega CR, Parola R, Carrera CS, 2018. Heat and water stressed field-grown soybean: A multivariate study on the relationship between physiological-biochemical traits and yield. Environ. Exp. Bot. 148:1-11.

Fanaei HR, Galavi M, Kafi M, Ghanbari Bonjar A, 2009. Amelioration of water stress by potassium fertiliser in two oilseed species. Int. J. Plant Prod. 3:41-54.

FAO, 2019. Food outlook. Global Market Analysis. Available from: http://www.fao.foodoutlook.com

Faraji A, Latifi N, Soltani A, Shirani Rad AH, 2008. Effect of high temperature stress and supplemental irrigation on flower and pod formation in canola (Brassica napus L.) cultivars at Mediterranean climate. Asian J. Plant Sci. 7:343-51.

Farhoudi R, Modhej A, Afrous A, 2015. Effect of salt stress on physiological and morphological parameters of rapeseed cultivars. J. Sci. Res. Dev. 2:111-7.

Ferrat IL, Lovatt CJ, 1999. Relation between relative water content, nitrogen pools, and growth of Phaseolus vulgaris L. and P. acutifolius A. Gray during water deficit. Crop Sci. 39:467-75.

Ghasemyan Ardestani H, Shirani Rad AH, 2012. Impact of regulated deficit irrigation on the physiological characteristics of two rapeseed varieties as affected by different potassium rates. Afr. J. Biotechnol. 11:6510-9.

Gill SS, Tuteja N, 2010. Reactive oxygen species and antioxidant machinery in abiotic stress tolerance in crop plants. Plant Physiol. Biochem. 48:909-30.

Godarzi A, Bazrafshan F, Zare M, Faraji H, Safahani Langeroodi AR, 2017. Studying the effect of drought stress on yield and physiological characteristics in genotypes of canola (Brassica napus L.). Helix 8:1250-1258.

Gogoi B, Kurmi K, Thakuria K, Ojha NJ, Dutta S, 2017. Influence of crop management practices on late sown toria (Brassica campestries var. toria) under rainfed rice-fallow situation of Assam. J. Oilseed Brassica. 8:168-74.

Ilkaee MN, Paknejad F, Zavareh M, Ardakani MR, Kashani A, 2011. Prediction model of leaf area in soybean (Glycine max L.). Am. J. Agric. Biol. Sci. 6:110-3.

Li S, Liu J, Liu Z, Li X, Wu F, He Y, 2014. Heat-induced task target mediates thermos-tolerance via heat stress transcription factor Ala-directed pathway in Arabidopsis. Plant Cell. 26:1764-80.

Liu EK, Mei XR, Yan CR, Gong DZ, Zhang YQ, 2016. Effects of water stress on photosynthetic characteristics, dry matter translocation and WUE in two winter wheat genotypes. Agric. Water Manag. 167:75-85.

Mamnabi S, Nasrollahzadeh S, Ghassemi-Golezani K, Raei Y, 2020. Improving physiological traits and grain yield of spring rapeseed by integrated fertiliser management under water deficit. Saudi J. Biol. Sci. 27:797-804.

Mason RE, Singh RP, 2014. Considerations when deploying canopy temperature to select high yielding wheat breeding lines under drought and heat stress. Agron. 4:191-201.

Moieni Korbekandi Z, Karimzadeh G, Sharifi M, 2014. Coldinduced changes of proline, malondialdehyde and cchlorophyll in spring canola cultivars. J. Plant Physiol. Breed. 4:1-11.

Moradi Aghdam A, Seyfzadeh S, Shirani Rad AH, Valadabadi SA, Zakerin H, 2018. Effect of irrigation cut on physiological characteristics and seed yield of canola cultivars under different sowing date. Crop Physiol. 10:59-76. [In Persian].

Moslemi Z, Habibi D, Asgharzadeh A, Ardakani MR, Mohammadi
A, Sakari A, 2011. Effects of super absorbent polymer and plant growth promoting rhizobacteria on yield and yield components of maize under drought stress and normal conditions. Afr. J. Agric. Res. 6:4471-6.

Nazeri P, Shirani Rad AH, Valad Abadi SA, Mirakhori M, Hadidi Masoule E, 2018. Effect of sowing dates and late season water deficit stress on quantitative and qualitative traits of canola cultivars. Outlook Agric. 47:291-7.

Neupane D, Solomon JK, Mclennon E, Davison J, Lawry T, 2019. Sowing date and sowing method influence on camelina cultivars grain yield, oil concentration, and biodiesel production. Food Energy Secur. 8:e00166.

Norouzi M, Toorchi M, HosseiniSalekdeh G, Mohammadi SA, Nishabouriand MR, Aharizad S, 2008. Effect of water deficit on growth, grain yield and osmotic adjustment in rapeseed. J. Food Agric. Environ. 6:132-8.

Ozer H, 2003. Sowing date and nitrogen rate effects on growth, yield and yield components of two summer rapeseed cultivars. Eur. J. Agron. 19:453-63.

Pasban Eslam B, Shakiba MR, Neyshabori MR, Moghaddam M, Ahmadi MR, 2000a. Effects of water stress on quality and quantity characteristics of rapeseed. J. Agric. Sci. 10:75-85.

Pasban Eslam B, Shakiba MR, Neyshabori MR, Moghaddam M, Ahmadi MR, 2000b. Evaluation of physiological indices as a screening technique for drought resistance in oilseed rape. Pak. Acad. Sci. J. 37:143-52.

Pasban Eslam B, Monirifar H, Sadeghi Bakhtavari AR, 2017. Morpho-physiological response of rapeseed (Brassica napus L.) genotypes to drought stress. Crop Breed. J. 7:49-56.

Prasad B, Babar MA, Xu XY, Bai GH, Klatt AR, 2009. Genetic diversity in the U.S. hard red winter wheat cultivars as reveled by microsatellite markers. Crop Pasture Sci. 60:16-24.

Raza I, Masood MA, Abid S, Rani S, Zahra N, Abbas H, 2019. Study of genetic diversity in rapeseed and mustard germplasm by using cluster analysis. J. Appl. Biotechnol. Bioeng. 6:242-5.

Raza MAS, Shahid AM, Saleem MF, Khan IH, Ahmad S, Ali M, Iqbal R, 2017. Effects and management strategies to mitigate drought stress in oilseed rape (Brassica napus L.): a review. Zemdirbyste 104:85-94.

Sabagh AE, Hossain A, Barutçular C, Islam MS, Ratnasekera D, Kumar N, Meena RS, Gharib HS, Saneoka H, Teixeira da Silva JA, 2019. Drought and salinity stress management for higher and sustainable canola (Brassica napus L.) production: A critical review. Aust. J. Crop Sci. 13:88-96.

Safavi Fard N, Heidari Sharif Abadb H, Shirani Rad AH, Majidi Heravan E, Daneshian J, 2018. Effect of drought stress on qualitative characteristics of canola cultivars in winter cultivation. Ind. Crops Prod. 114:87-92.

Safdari Monfared N, Noor Mohammadi G, Shirani Rad AH, Majidi Heravan E, 2019. Effect of sowing date and glycinebetaine on seed yield, oil content, and fatty acids in rapeseed cultivars. J. Agr. Sci. Tech. 21:1495-506.

Shekari F, Soltaniband V, Javanmard A, Abbasi A, 2015. The impact of drought stress at different stages of development on water relations, stomatal density and quality changes of rapeseed (Brassica napus L.). Iran Agric. Res. 34:81-90.

Shirani Rad AH, Bitarafan Z, Rahmani F, Taherkhani T, Moradi Aghdam A, Nasresfahani S, 2014a. Effects of planting date on spring rapeseed (Brassica napus L.) cultivars under different irrigation regimes. Turk. J. Field Crop 19:153-7.

Shirani Rad AH, Bitarafan Z, Rahmani F, Taherkhani T, Moradi Aghdam A, Nasresfahani S, 2014b. Evaluation of spring rapeseed (Brassica napus L.) cultivars for different planting dates 
and irrigation regimes. J. Anim. Plant Sci. 24:1166-72.

Shweta M, Agrawal SB, 2006. Interactive effect between supplemental ultraviolet-B radiation and heavy metals under growth and biochemical characteristics of Spinacia oleracea L. Braz. J. Plant Physiol. 18:307-14.

Siadat SA, Hemayati SS, 2009. Effect of sowing date on yield and yield components of three oilseed rape varieties. Acta Agron. Hung. 7:31-5.

Singer SD, Zou J, Weselake RJ, 2016. Abiotic factors influence plant storage lipid accumulation and composition. Plant Sci. 243:1-9.

Tambussi EA, Bartoli CG, Bettran J, Guiamet JJ, Araus JC, 2000. Oxidative damage to thylakoids proteins in water stressed leaves of wheat (Triticum aestivum L.). Physiol. Plant. 108:398-404.

Teymoori M, Ardakani MR, Shirani Rad AH, Alavifazel M, Nejatkhah Manavi P, 2020. Seed yield and physiological responses to deal with drought stress and late sowing date for promising lines of rapeseed (Brassica napus L.). Int. Agrophys. 4:321-31.

Turhan H, Gul MK, Egesel CO, Kahriman F, 2011. Effect of sowing time on grain yield, oil content, and fatty acids in rapeseed
(Brassica napus subsp. oleifera). Turk. J. Agric. For. 35:225-34. USDA Economic Research Service, 2020. Oil Crops Data: Yearbook Tables, Canola. U.S. Gov. Print. Office, Washington, DC, USA. Available from: https://www.ers.usda.gov/webdocs/DataFiles/52218/AllYearbook\%20tables.pdf?v=0

Uzun B, Zengin U, Furat S, Akdesir O, 2009. Sowing date effects on growth, flowering, oil content and seed yield of canola cultivars. Asian J. Chem. 21:1957-65.

Viger M, Rodriguez Acosta M, Rae AM, Morison JI, Taylor G, 2013. Toward improved drought tolerance in bioenergy crops: QTL for carbon isotope composition and stomatal conductance in Populus. Food Energy Secur. 2:220-36.

Wu W, Ma BL, Whalen JK, 2018. Enhancing rapeseed tolerance to heat and drought stresses in a changing climate: perspectives for stress adaptation from root system architecture. Adv. Agron. 151:87-157.

Yousuf M, Ajmal SU, Munir M, Ghafoor A, 2011. Genetic diversity analysis for agro-morphological and seed quality traits in rapeseed (Brassica campestris L.). Pak. J. Bot. 43:1195-203.

Zeleke KT, Luckett DJ, Cowley RB, 2014. Response of canola (Brassica napus L.) and mustard (B. juncea L.) to different watering regimes. Exp. Agric. 50:573-90. 